Zitelny, H., Dror, T., Altman, S., \& Bar-Anan, Y., (in press). The Relation Between Gender Identity and Well-Being. Personality and Social Psychology Bulletin

\title{
The Relation Between Gender Identity and Well-Being
}

Hila Zitelny ${ }^{\mathrm{a}}$, Tzipi Dror ${ }^{\mathrm{b}}$, Shahar Altman $^{\mathrm{b}}$, Yoav Bar-Anan ${ }^{\mathrm{b}}$

a Psychology Department, Ben-Gurion University of the Negev, Beersheba, Israel;

${ }^{\mathrm{b}}$ School of Psychological Sciences, Tel-Aviv University, Tel-Aviv, Israel

Author Note:

The first and second authors contributed equally to this manuscript.

Word-count: 9,912 


\begin{abstract}
Does strong gender identity help or harm one's well-being? Previous research suggests that acceptance of one's social group and feelings of belongingness to the group are positively related to well-being, regardless of the group's social status. However, there are inconsistent findings about the relation between well-being and how central the group is to one's identity (centrality), especially among disadvantaged groups (e.g., women). In Studies 1-10 (total $N=$ $5,955)$, we clarified these relations by controlling for shared variance between distinct gender identity aspects. Acceptance and belongingness were positively related to a range of wellbeing variables. Centrality was negatively related to well-being. These results were consistent across genders. Studies 11-14 (total $N=2,380$ ) found that the negative relation between centrality and well-being might be mediated by perceived pressure to conform to the masculine-role among men, and perceived gender inequality among women. These results uncover a burden of strong gender identity.
\end{abstract}

Keywords: multifaceted social identity; gender identity; social identity; well-being 


\section{The Relation Between Gender Identity and Well-Being}

The self-concept is composed of individuals' memories and notions about who they are, their traits, behavioral habits and thinking patterns (Oyserman, 2001). A central part of the self-concept is social identity - people's "knowledge of their membership of a social group (or groups) together with the value and emotional significance attached to that membership" (Tajfel, 1981). Theory and research suggest that social identities are not a monolithic structure. Rather, they are comprised of a number of dimensions that are related but not identical to each other (Ashmore et al., 2004; Cameron, 2004; Leach et al., 2008). Tajfel's (1981) classic definition is often interpreted as pointing towards three facets of social identity (e.g., Cameron, 2004; Ellemers et al., 1999; Jackson, 2002). The first facet is awareness of group membership ("knowledge of their membership of a social group") which is usually interpreted as the salience, importance, and centrality of group membership in one's self-concept (Cameron, 2004; Schmader \& Block, 2015). The second facet consists of group evaluation and the positivity of feelings associated with group membership ("value"). The third facet reflects feelings of belongingness, similarity, and bond with other group members (“emotional significance").

In the present work, we examined the relation between gender identity, one of the main social identities that people adopt (Schmader \& Block, 2015; Spence, 1999), and wellbeing. Well-being encompasses a broad spectrum of components such as happiness, life satisfaction, fulfillment, positive and negative affective reactions to one's experiences, and stress (Busseri \& Sadava, 2010; Linley et al., 2009). Specifically, we focused on the relation between well-being and the three gender identity facets described above, and tested whether these relations vary by group status. 


\section{Theoretical Background}

\section{Group Evaluation and Belongingness}

Theory and research suggests that identification and belonging to a group is a basic human motivation and behavior, which generally promotes well-being (Baumeister \& Leary, 1995). Social groups provide their members with strong support, personal security, emotional bonding, sense of belonging, and meaning. These, in turn, promote positive self-perceptions and well-being regardless of the social status of the group (Greenaway et al., 2016; Haslam et al., 2009).

The rejection-identification model (RIM; Branscombe et al., 1999) lends further support for a positive relation between well-being and feelings of belongingness and positive feelings regarding group membership, especially among members of disadvantaged groups. According to the RIM, members of disadvantaged groups have lower well-being, in comparison to members of the advantaged outgroup, but when they feel rejected by an outgroup, they tend to amplify their identification with their ingroup. This promotes feelings of belongingness and inclusion in their ingroup, which in turn buffer the negative effects of discrimination and contribute to their well-being. As a result, members of dominant groups and non-dominant groups alike would show better well-being the more they feel belongingness to the group and positive affect toward this belongingness.

\section{Centrality and Salience}

Theories that focused on the centrality of the group membership in one's self-identity suggest that members of low-status groups would show worse well-being the more their group is a salient and central aspect of their identity. According to the reflected appraisals model (Gentile et al., 2009; Khanna, 2004; Twenge \& Campbell, 2002), people form selfconceptions on the basis of others' attitudes and perceptions towards the group they belong to. This notion is similar to social identity theory's (Tajfel \& Turner, 1979) assumption that 
social identity contributes to people's self-concept because people evaluate themselves according to their group and in relation to other groups. Therefore, social identity might cause negative perception of oneself, if the group is stigmatized or suffers from low status. Based on these models, it seems plausible that women whose gender is a central aspect of their identity would internalize the negative stigma and stereotypes that are socially attributed to women.

Major and colleagues' discounting model (Crocker \& Major, 1989; Eccleston \& Major, 2006; Major et al., 2002, 2003; McCoy \& Major, 2003) lends further support to the possibility of a negative relation between social identity and well-being, among members of low-status groups. According to the discounting model, belonging to a low status group can be harmful to one's well-being (additional theories also provide support for this hypothesis; e.g., Emerson, 1976; Fazio et al., 1981; Gecas \& Schwalbe, 1983; Harrell et al., 2011). Members of low status groups, who are chronically exposed to prejudice and discrimination, learn to employ various discounting mechanisms that buffer against the negative effects of discrimination. When one's membership in a disadvantaged group is more central or salient and is viewed as a core aspect of the self, this is linked to a greater awareness of the problems and difficulties that group members have to cope with. As a result, the protective discounting mechanisms become less effective, which can negatively impact one's well-being (Major et al., 2002; McCoy \& Major, 2003).

Given that women are disadvantaged, often perceived and judged through the lens of derogating stereotypes and sexist attitudes (Rudman \& Glick, 2012), high salience and centrality of their gender identity might harm them. Indeed, previous research has found that when gender identity is conceptualized as identity's salience, importance, and centrality, stronger gender identity can be harmful for women. One example comes from research on stereotype threat: When women's gender is very important to them or is made salient, they 
have a greater motivation to maintain a positive image of their gender group, which makes stereotype threatening situations more stressful for them (Shapiro \& Neuberg, 2007; Steele et al., 2002). This impedes their ability to perform, and as a result they end up fulfilling sexist expectations of poor math ability (Casad et al., 2017; Schmader, 2002; Shih et al., 1999). In a different example, women who reflected on their feelings about themselves as women, perceived a sexist comment as more prejudiced than women who reflected on their feelings about themselves in general (Wang \& Dovidio, 2017).

As for men, a group with high social status, different theories predict contradicting relations between well-being and the centrality and salience of gender in their self-identity. According to the reflected appraisals model (Gentile et al., 2009) and social identity theory (Tajfel \& Turner, 1979), when the group is socially valued, strong identity centrality may contribute to positive self-perceptions, which is positively related to well-being. On the other hand, theory and research have suggested that manhood is perceived in society as a precarious state that needs continual validation (Vandello \& Bosson, 2013). Because manhood is precarious, men are sensitive to gender threats that undermine their masculinity and feel anxiety and anger, leading to aggressive behavior (Dahl et al., 2015; Glick et al., 2007). Thus, men whose gender is a crucial part of their identity might be more sensitive to the burden of masculinity, which might harm their well-being.

Viewing manhood as precarious may also encourage the perception that while, as a man, one has an advantageous status, one is also under a constant threat of losing one's membership in that high-status group (Vandello \& Bosson, 2013). This alternative possibility leads to a parsimonious account for the negative relation between gender centrality and wellbeing by attributing this relation a perceived threat to one's social status. Among women, it reflects the perception that women are disadvantaged. Among men, it reflects the perception that they can cease to be advantaged if they do not maintain their manhood. 


\section{Previous Research}

Most research that studied the relation between social identity and well-being has usually treated social identity as a cohesive and uniform construct (Bourguignon et al., 2006; Crabtree et al., 2010; Cruwys et al., 2014; Greenaway et al., 2016; Phinney et al., 1997; Sani et al., 2012; Tate et al., 2015; Van Dick et al., 2017; Wakefield et al., 2018). Only a few studies have examined the relation between well-being and social identity from a multifaceted perspective. Table 1 summarizes the results of a selective sample of these studies. These studies found that facets related to belongingness and bond with ingroup members were usually associated with better well-being no matter the status of the group (Egan \& Perry, 2001; Hughes et al., 2015; Rubin \& Stuart, 2018; Smith \& Leaper, 2006), but were sometimes associated with worse well-being (Cruwys \& Gunaseelan, 2016). Similarly, facets related to positive affect towards the group and its members were usually predictive of better well-being (Egan \& Perry, 2001; Hoffman, 2006; Hughes et al., 2015; Roszak, 2010; Rowley et al., 1998; Settles et al., 2009; Smith \& Leaper, 2006; Yap et al., 2011), but were sometimes associated with worse or had no relation to well-being (Cruwys \& Gunaseelan, 2016; Egan \& Perry, 2001; Smith \& Leaper, 2006)

There is mixed evidence about the relation between identity centrality and well-being. Among members of minority groups and women, facets involving aspects of identity centrality, salience, and importance had inconsistent relations with well-being, showing positive (Roszak, 2010; Yap et al., 2011), negative (Cruwys \& Gunaseelan, 2016; Rubin \& Stuart, 2018), or no relation at all (Hoffman, 2006; Settles et al., 2009). Among members of majority groups and men, these facets showed positive (Roszak, 2010; Rubin \& Stuart, 2018) or no relations with well-being (Hoffman, 2006). 
Table 1

Selective Sample of Previous Studies That Tested the Relation Between Social Identity Facets and Well-Being

Study

Cruwys \&

Gunaseelan, 2016

Hughes et al., 2015

Rowley et al., 1998

positive affect towards the
group

Rubin \& Stuart, $\quad$ Perceived similarity group

2018

\begin{tabular}{lll}
\hline Yap, et al., 2011 & $\begin{array}{l}\text { Perceptions of others' } \\
\text { positive affect towards the } \\
\text { group }\end{array}$ & $\begin{array}{l}\text { Positive affect associated } \\
\text { with membership in the } \\
\text { group }\end{array}$ \\
\hline
\end{tabular}

\section{Facets of gender identity among women}

\begin{tabular}{|c|c|c|c|c|}
\hline $\begin{array}{l}\text { Egan \& Perry, } \\
2001\end{array}$ & $\begin{array}{l}\text { Perceived identity } \\
\text { typicality }\end{array}$ & $\begin{array}{l}\text { Perceived-pressure to } \\
\text { conform to group } \\
\text { expectations }\end{array}$ & $\begin{array}{l}\text { Identity } \\
\text { contentedness }\end{array}$ & Intergroup bias \\
\hline Hoffman, 2006 & Identity acceptance & Identity centrality & & \\
\hline Roszak, 2010 & Identity acceptance & Identity centrality & & \\
\hline Settles et al., 2009 & Identity satisfaction & Identity centrality & & \\
\hline
\end{tabular}




\begin{tabular}{llll}
\hline $\begin{array}{l}\text { Smith \& Leaper, } \\
2006\end{array}$ & $\begin{array}{l}\text { Perceived identity } \\
\text { typicality }\end{array}$ & $\begin{array}{l}\text { Perceived-pressure to } \\
\text { conform to group } \\
\text { stereotypes }\end{array}$ & $\begin{array}{l}\text { Identity } \\
\text { contentedness }\end{array}$ \\
\end{tabular}

Facets of social identity among members of majority groups (not gender)

\begin{tabular}{llll}
\hline $\begin{array}{l}\text { Rubin \& Stuart, } \\
2018\end{array}$ & Perceived similarity & Identity importance & \multicolumn{1}{c}{ Identity salience } \\
\hline Egan \& Perry, & Perceived identity & \multicolumn{1}{c}{ Facets of gender identity among men } \\
2001 & typicality & $\begin{array}{l}\text { Perceived-pressure to } \\
\text { conform to group } \\
\text { expectations }\end{array}$ & $\begin{array}{l}\text { Identity } \\
\text { contentedness }\end{array}$ \\
\hline Hoffman, 2006 & Identity acceptance & Identity centrality & \\
\hline Roszak, 2010 & Identity acceptance & Identity centrality & \\
\hline Smith \& Leaper, & Perceived identity & $\begin{array}{l}\text { Perceived-pressure to } \\
\text { conform to group }\end{array}$ & $\begin{array}{l}\text { Identity } \\
\text { contentedness }\end{array}$ \\
& typicality & stereotypes & \\
\hline
\end{tabular}

Note. Positive relations in green, negative relations in red, no reliable relations in black. 


\section{The Present Research}

One possibility that may account for the inconsistent evidence about the relations between the gender identity facets and well-being is the statistical method used to test these relations, namely, simple correlations. Simple correlations might not be the suitable test because different facets of social identity share common properties and correlate with one another (e.g., Cameron, 2004). For instance, those who feel uncomfortable and dissatisfied with their gender might perceive themselves as less typical, and therefore might minimize the centrality of gender to their identity. Due to those covariations, it might be more informative to examine the unique variance that each gender identity facet shares with well-being, after controlling for the other facets. That approach might help uncover the unique role of each gender identity facet in people's well-being. In the present research, we followed that rationale and used multiple regression analysis to examine the relations between various gender identity facets and a number of variables related to well-being.

To recapitulate, previous theory and research suggest that gender identity facets of belongingness and positive affect towards one's gender group capture the positive impact of gender identity on well-being (e.g., Baumeister \& Leary, 1995; Branscombe et al., 1999). In contrast, the relation between well-being and the centrality and salience of gender in one's identity might depend on the social status of the gender, as suggested by the reflected appraisals model (e.g., Gentile et al., 2009), social identity theory (Tajfel \& Turner, 1979), and the discounting model (e.g., Major et al., 2002). In that case, high centrality and salience of gender would be negatively related to well-being among women (the disadvantaged group) and positively related to well-being among men (the privileged group). Yet, the perspective that views manhood as precarious (Vandello \& Bosson, 2013) provides grounds to the possibility that salient male gender identity could be a burden on men's well-being because it emphasizes masculinity expectations and the fragility of men's advantaged status if these 
expectations are not met. The relevant previous evidence is inconsistent, perhaps because it relied mostly on simple correlations. The present research tested the relations between various gender identity facets and a number of well-being measures, after controlling for shared variance among the gender identity facets.

In Studies 1-10, we tested whether various measures of well-being are positively or negatively related to different facets of gender identity, after controlling for shared variance among the facets. Table 2 presents the well-being variables we measured and the participants' gender in each study.

To verify that our results generalize beyond specific measures of gender identity, we used two sets of gender identity measures, each included three facets. In Studies 1-5, 7, and 8, we measured gender typicality (Tate et al., 2015), gender acceptance, and gender definition (Hoffman et al., 2000). In Studies 6, 9, and 10, as a conceptual replication, we used three subscales of the same social identity scale: ingroup ties, ingroup affect, and centrality (Cameron, 2004). Each of these two sets of gender identity measures included a measure of belongingness and assimilation in one's gender group (gender typicality; ingroup ties), positive affect associated with being a woman/man (gender acceptance; ingroup affect), and centrality of the gender component in the identity (gender definition; centrality). While the two sets of gender identity facet measures are not identical, and sometimes emphasize different aspects of each identity facet (e.g., gender typicality emphasizes similarity to ingroup members whereas ingroup ties emphasizes feelings of belongingness to the ingroup), they are similar enough to each other in order to serve as conceptual replications for one another. In Studies 11-14, we explored the mechanisms that underlie the relations found in Studies 1-10, by testing possible mediators. 


\section{Studies 1-10}

\section{Method}

All the materials and data files for the reported studies are available online at anonymized link [will be replaced upon publication]. The studies included three measures of gender identity and at least one measure of a variable related to well-being (see Table 2). The relation between gender identity and well-being was a central research question in these studies, but some studies also pursued other goals. As a result, each of these studies also included measures that were exploratory or unrelated to the present research question (see anonymized link for full methods and results pertaining to these measures). Choosing to report a subset of measures from a study increases the researcher's degrees of freedom and decreases confidence in the results (Simmons et al., 2011). In Studies 1-10, however, because the results were consistent across many studies, and included multiple direct and conceptual replications, we are confident that they were not a statistical fluke.

\section{Participants}

Participants in the web studies were volunteers at Project Implicit website (implicit.harvard.edu; Nosek, 2005). These volunteers registered to participate in research studies at the website (rather than demonstration IAT studies), and were randomly assigned to the study, based on pre-specified inclusion rules, allowing only women in Studies 1-3, 5, and 6, and only men in Studies 7-10. The dates of the studies did not overlap. Participants could not be assigned to more than one study. Participants in the lab study (Study 4) were university students who received course credit or monetary compensation for their participation. In each study, the analyses included only participants who completed all the questionnaires that were relevant to that study (Table 2). 


\section{Procedure}

In the web studies, participants completed the gender identity questionnaires (presented in a random order) before the well-being measures. In Study 4 (the lab study), participants first completed either self-esteem or gender identity questionnaires (in a random order). Next, they answered guilt and shame proneness, life satisfaction, and depressive symptoms questionnaires.

\section{Measures}

See Tables 3 (women) and 6 (men) for the measures' internal consistency. All the scales were validated in previous research and scored as instructed. Unless indicated otherwise, all scores were the average rating.

Gender Identity. Across all gender identity variables, higher scores indicated stronger identification with one's gender. Unless indicated otherwise, the response scale to all questions was a 1-6 agreement scale.

Gender Typicality. Participants rated their similarity to other women or men with six items (Tate et al., 2015; e.g., Ifeel just like women/men my age), rated on a 1-to-7 agreement scale.

Gender Acceptance. Participants rated the extent to which they feel comfortable and satisfied as women or men with seven items (self-acceptance subscale of the Hoffman gender scale; Hoffman et al., 2000; e.g., I meet my personal standards for femininity/masculinity).

Gender Definition. Participants rated the extent to which femininity or masculinity is centrally integrated in their identity with seven items (self-definition subscale of the Hoffman gender scale; Hoffman et al., 2000; e.g., When I am asked to describe myself, being female/male is one of the first things I think of). 
Table 2

Studies 1-10: Demographics and Main Variables

\begin{tabular}{|c|c|c|c|c|c|c|c|c|}
\hline Study & $N$ & Gender & $\begin{array}{l}\text { Mean age } \\
(S D)\end{array}$ & $\%$ White & $\%$ USA & Gender identity Facets & Well-being variables & $\begin{array}{l}\text { Excluded participants } \\
\text { due to missing data }\end{array}$ \\
\hline 1 & 487 & f & $35.1(14.3)$ & 71.1 & 75.5 & Typicality, acceptance, definition & Self-esteem & 11 \\
\hline 2 & 640 & $\mathrm{f}$ & $38.7(14)$ & 71.7 & 71.1 & Typicality, acceptance, definition & Self-esteem & 4 \\
\hline 3 & 636 & $\mathrm{f}$ & $38.2(13.8)$ & 73.9 & 67.9 & Typicality, acceptance, definition & Shame and guilt proneness & 13 \\
\hline $4(\mathrm{lab})$ & 200 & $\mathrm{f}$ & $23.3(1.5)$ & ----------- & --------- & Typicality, acceptance, definition & $\begin{array}{l}\text { Self-esteem, shame and guilt } \\
\text { proneness, life satisfaction, } \\
\text { and depressive symptoms }\end{array}$ & 35 \\
\hline 5 & 568 & $\mathrm{f}$ & $38.8(13.7)$ & 72.7 & 65.9 & Typicality, acceptance, definition & Self-objectification & 14 \\
\hline 6 & 1,115 & $\mathrm{f}$ & $33.6(14.5)$ & 68.3 & 68.9 & Ingroup ties, ingroup affect, centrality & $\begin{array}{l}\text { Self-esteem, shame and guilt } \\
\text { proneness, and self- } \\
\text { objectification }\end{array}$ & 76 \\
\hline 7 & 538 & $\mathrm{~m}$ & $39.8(13.9)$ & 70.6 & 62.6 & Typicality, acceptance, definition & $\begin{array}{l}\text { Self-esteem and self- } \\
\text { objectification }\end{array}$ & 27 \\
\hline 8 & 576 & $\mathrm{~m}$ & $40.4(15.0)$ & 71.7 & 59.8 & Typicality, acceptance, definition & $\begin{array}{l}\text { Shame and guilt proneness } \\
\text { and life satisfaction }\end{array}$ & 19 \\
\hline 9 & 586 & $\mathrm{~m}$ & $39.4(14.6)$ & 71.8 & 59.6 & Ingroup ties, ingroup affect, centrality & $\begin{array}{l}\text { Self-esteem and self- } \\
\text { objectification }\end{array}$ & 21 \\
\hline 10 & 609 & $\mathrm{~m}$ & $40.3(14.6)$ & 70.2 & 60.6 & Ingroup ties, ingroup affect, centrality & $\begin{array}{l}\text { Shame and guilt proneness } \\
\text { and life satisfaction }\end{array}$ & 15 \\
\hline
\end{tabular}


Ingroup Affect. Participants rated the positivity of their feelings regarding being a member of the women or men group with four items (ingroup affect subscale; Cameron, 2004; e.g., In general, I'm glad to be a woman/man).

Centrality. Participants rated the importance of gender to their self-definition and the frequency with which it comes to their mind with four items (centrality subscale; Cameron, 2004; e.g., In general, being a woman/man is an important part of my self-image).

\section{Well-Being.}

Self-Esteem. Rosenberg's Self-esteem Scale (Rosenberg, 1965) assessed self-esteem with ten 1-to-4 agreement scale items (e.g., On the whole, I am satisfied with myself). Higher scores indicate higher self-esteem.

Shame and Guilt Proneness. The Personal Feelings Questionnaire-2 (Harder \& Zalma, 1990) assessed proneness to shame and guilt. Participants rated the frequency they tend to feel various feelings from 0 (I do not experience the feeling) to 4 (I experience the feeling very strongly). The list of feelings included six guilt items (e.g., Mild guilt), ten shame items (e.g., Embarrassment), and six fillers. Shame and guilt scores were calculated separately, with higher scores representing stronger tendency to experience these emotions (i.e., lower well-being).

Life Satisfaction. The Satisfaction with Life Scale (Diener et al., 1985) assessed life satisfaction with five 1-to-7 agreement scale items (e.g., In most ways my life is close to my ideal). Higher scores indicated better life satisfaction.

Depressive Symptoms. The Beck depression Inventory II (Beck et al., 1996) assessed depressive symptoms severity with a 21-item questionnaire. Participants rated depressive symptoms in the past two weeks on a 0-to-3 severity scale. Depression scores were a sum of all items, with higher scores indicating more severe depression. 
Self-Objectification. Two subscales from the Objectified Body Consciousness Scale (McKinley \& Hyde, 1996) assessed self-objectification. Using a 1-to-7 agreement scale, participants completed the body surveillance scale (eight items, e.g., During the day, I think about how I look many times) and the body shame scale (eight items, e.g., When I'm not the size I think I should be, Ifeel ashamed). A mean of the items in each scale was its score. In line with prior research, a third scale (control beliefs) was not included (Fairchild \& Rudman, 2008; Muehlenkamp \& Saris-Baglama, 2002; Tiggemann \& Kuring, 2004). In addition, as in previous research (e.g., Fairchild \& Rudman, 2008), the two scales strongly correlated with one another $(r \mathrm{~s}=.568, .577, .518, .552$; Cronbach's $\alpha=.888, .884, .855, .879)$, therefore they were averaged to represent self-objectification score. Higher scores indicated stronger selfobjectification.

\section{Results}

\section{Studies 1-6: Women}

Table 3 presents descriptive statistics, Table 4 presents the correlations, and Table 5 presents the regression coefficients in the analyses that tested the relation between gender identity measures and well-being measures (see the Appendix for full results of the multiple regression analyses). Studies 1-6 showed consistent results: the correlation tests found that better well-being was associated with stronger gender acceptance and ingroup affect, and often also with stronger gender typicality and ingroup ties. These relations usually remained the same when tested in a multiple regression analysis. As for gender definition and centrality, after controlling for shared variance with measures of other facets of gender identity, stronger gender definition and centrality consistently predicted lower levels of wellbeing. In the correlation tests, gender definition and centrality were sometimes positively associated with well-being, sometimes negatively, and sometimes had no relation with the well-being measures. 
Specifically, in Studies 1, 2, and 4, gender typicality $(\beta=.175, .112[p=.004], .231$, all $\mathrm{p}$-values were below .001, unless specified) and gender acceptance $(\beta s=.540, .509, .633)$ predicted higher self-esteem, whereas gender definition emerged as a negative predictor of self-esteem $(\beta=-.291,-.254,-.264[p=.002])$. In Study 6, ingroup ties $(\beta=.139)$ and ingroup affect $(\beta=.414)$ predicted higher self-esteem, whereas centrality predicted lower self-esteem $(\beta=-.090, p=.001)$.

In Studies 3, 4, and 6, shame and guilt proneness showed a similar pattern to the pattern described above for self-esteem: gender acceptance always predicted positive wellbeing (lower shame and guilt), whereas gender centrality always predicted negative wellbeing (higher shame and guilt). Specifically, in Study 3, whereas gender acceptance predicted lower levels of proneness to shame $(\beta=-.392)$ and guilt $(\beta=-.275)$, gender definition predicted higher levels of these emotions (shame: $\beta=.224$; guilt: $\beta=.173$ ). Gender typicality did not share unique variance with shame and guilt proneness (shame: $\beta=-.021, p=.631$; guilt: $\beta=-.034, p=.454)$.

In Study 4, whereas gender typicality and gender acceptance predicted lower shame proneness (typicality: $\beta=-.182, p=.012$; acceptance: $\beta=-.529$ ) and guilt proneness (typicality: $\beta=-.182, p=.017$; acceptance: $\beta=-.364$ ), gender definition predicted higher proneness to shame and guilt (shame: $\beta=.317$; guilt: $\beta=.240, p=.014$ ).

In Study 6, Ingroup ties and ingroup affect predicted lower shame (ties: $\beta=-.114$; affect: $\beta=-.298$ ) and guilt proneness (ties: $\beta=-.063, p=.048$; affect: $\beta=-.278$ ), whereas centrality predicted higher proneness to shame $(\beta=.161)$ and guilt $(\beta=.201)$.

Similar patterns emerged when testing the relations of gender identity with life satisfaction and depressive symptoms. In Study 4, whereas gender typicality and gender acceptance predicted higher life satisfaction $(\beta s=.293, .535$, respectively) and fewer depressive symptoms $(\beta=-.277,-.438)$, gender definition had the exact opposite relations, 
predicting lower life satisfaction $(\beta=-.230)$ and more depressive symptoms $(\beta=.223, p=$ $.014)$.

Finally, Studies 5 and 6 found a somewhat different pattern of results for selfobjectification, but still replicated the same central finding in the multiple regression: whereas gender acceptance/ingroup affect had a negative relation with self-objectification, gender definition/centrality had a positive relation with self-objectification. Gender typicality (Study 5) and ingroup ties (Study 6) had no unique contribution to self-objectification (typicality: $\beta=.065, p=.139$; ties: $\beta=.013, p=.686$ ), gender acceptance (Study 5) and ingroup affect (Study 6) were negative predictors of self-objectification (acceptance: $\beta=$ .429; affect: $\beta=-.242$ ), and gender definition (Study 5) and centrality (Study 6) were positive predictors of self-objectification (definition: $\beta=.376$; centrality: $\beta=.256$ ). 
Table 3

Studies 1-6 (Women): Mean (SD) and Cronbach's Alpha of the Main Variables

\begin{tabular}{|c|c|c|c|c|c|c|c|c|c|}
\hline \multirow[t]{2}{*}{ Study } & \multicolumn{3}{|c|}{ Gender Identity Facets } & \multirow[t]{2}{*}{ Self-esteem } & \multirow[t]{2}{*}{ Shame } & \multirow[t]{2}{*}{ Guilt } & \multirow[t]{2}{*}{ Life satisfaction } & \multirow[t]{2}{*}{ Depressive symptoms } & \multirow[t]{2}{*}{ Self-objectification } \\
\hline & Typicality & Acceptance & Definition & & & & & & \\
\hline 1 & $4.517(1.195)$ & $4.887(0.925)$ & $3.919(1.045)$ & $3.072(0.560)$ & & & & & \\
\hline$\alpha$ & .866 & .918 & .876 & .905 & & & & & \\
\hline 2 & $4.432(1.069)$ & $4.894(0.823)$ & $3.754(1.051)$ & $3.145(0.535)$ & & & & & \\
\hline$\alpha$ & .819 & .897 & .882 & .902 & & & & & \\
\hline 3 & 4.405 (1.138) & $4.808(0.882)$ & $3.742(1.057)$ & & $1.225(0.676)$ & $1.318(0.800)$ & & & \\
\hline$\alpha$ & .841 & .907 & .877 & & .855 & .841 & & & \\
\hline 4 & $4.513(1.097)$ & $4.526(0.960)$ & $3.601(0.989)$ & $3.112(0.601)$ & $1.367(0.612)$ & $1.499(0.823)$ & $4.799(1.210)$ & $10.860(8.561)$ & \\
\hline$\alpha$ & .880 & .924 & .856 & .931 & .793 & .852 & .880 & .905 & \\
\hline 5 & $4.410(1.170)$ & $4.910(0.818)$ & $3.747(1.073)$ & & & & & & $3.835(1.007)$ \\
\hline \multirow[t]{2}{*}{$\alpha$} & .854 & .892 & .879 & & & & & & .888 \\
\hline & Ingroup ties & Ingroup affect & Centrality & & & & & & \\
\hline 6 & $4.431(0.961)$ & $5.176(0.731)$ & $4.043(1.001)$ & $3.007(0.586)$ & $1.254(0.699)$ & $1.287(0.770)$ & & & $4.039(0.995)$ \\
\hline$\alpha$ & .818 & .771 & .722 & .904 & .861 & .816 & & & .884 \\
\hline
\end{tabular}


Table 4

Studies 1-6 (Women): Zero-Order Correlations Between Gender Identity and Well-Being

\begin{tabular}{|c|c|c|c|c|c|c|c|}
\hline & & $\begin{array}{l}\text { Self- } \\
\text { esteem }\end{array}$ & Shame & Guilt & $\begin{array}{l}\text { Life } \\
\text { satisfaction }\end{array}$ & $\begin{array}{l}\text { Depressive } \\
\text { symptoms }\end{array}$ & $\begin{array}{l}\text { Self- } \\
\text { objectification }\end{array}$ \\
\hline \multirow{5}{*}{ Typicality } & Study 1 & $.261 * * *$ & & & & & \\
\hline & Study 2 & $.188^{* * * *}$ & & & & & \\
\hline & Study 3 & & $-.089 *$ & -.074 & & & \\
\hline & Study 4 & $.419 * * *$ & $-.302 * * *$ & $-.256 * * *$ & $.450 * * *$ & $-.392 * * *$ & \\
\hline & Study 5 & & & & & & .038 \\
\hline Ingroup ties & Study 6 & $.281 * * *$ & $-.191 * * *$ & $-.121 * * *$ & & & -.017 \\
\hline \multirow{5}{*}{ Acceptance } & Study 1 & $.415^{* * *}$ & & & & & \\
\hline & Study 2 & .400 *** & & & & & \\
\hline & Study 3 & & $-.267 * * *$ & $-.185 * * *$ & & & \\
\hline & Study 4 & $.549^{* * *}$ & $-.384 * * *$ & $-.275 * * *$ & $.505 * * *$ & $-.405 * * *$ & \\
\hline & Study 5 & & & & & & $-.193 * * *$ \\
\hline Ingroup affect & Study 6 & $.456^{* * * *}$ & $-.320 * * *$ & $-.273 * * *$ & & & $-.199 * * *$ \\
\hline \multirow{5}{*}{ Definition } & Study 1 & $.153^{* * * *}$ & & & & & \\
\hline & Study 2 & $.083^{*}$ & & & & & \\
\hline & Study 3 & & -.02 & -.007 & & & \\
\hline & Study 4 & $.284 * * *$ & -.137 & -.095 & $.273 * * *$ & $-.202 * *$ & \\
\hline & Study 5 & & & & & & $.162 * * *$ \\
\hline Centrality & Study 6 & .008 & $.087 * *$ & $.144 * * *$ & & & $.224 * * * *$ \\
\hline
\end{tabular}


Table 5

Studies 1-6 (Women): Standardized Coefficients of Multiple Regression Analyses

\begin{tabular}{|c|c|c|c|c|c|c|c|}
\hline & & $\begin{array}{l}\text { Self- } \\
\text { esteem }\end{array}$ & Shame & Guilt & $\begin{array}{l}\text { Life } \\
\text { satisfaction }\end{array}$ & $\begin{array}{l}\text { Depressive } \\
\text { symptoms }\end{array}$ & $\begin{array}{l}\text { Self- } \\
\text { objectification }\end{array}$ \\
\hline \multirow{5}{*}{ Typicality } & Study 1 & $.175^{* * *} *$ & & & & & \\
\hline & Study 2 & $.122 * * *$ & & & & & \\
\hline & Study 3 & & -.021 & -.034 & & & \\
\hline & Study 4 & $.231 * * *$ & $-.182 *$ & $-.182 *$ & $.293 * * *$ & $-.277 * * *$ & \\
\hline & Study 5 & & & & & & .065 \\
\hline Ingroup ties & Study 6 & $.139 * * *$ & $-.114 * * *$ & $-.063 *$ & & & .013 \\
\hline \multirow{5}{*}{ Acceptance } & Study 1 & $.540 * * *$ & & & & & \\
\hline & Study 2 & $.509 * * *$ & & & & & \\
\hline & Study 3 & & $-.392 * * *$ & $-.275 * * *$ & & & \\
\hline & Study 4 & $.633 * * *$ & $-.529 * * *$ & $-.364 * * *$ & $.535 * * *$ & $-.438 * * *$ & \\
\hline & Study 5 & & & & & & $-.429 * * *$ \\
\hline Ingroup affect & Study 6 & $.414 * * *$ & $-.298 * * *$ & $-.278 * * *$ & & & $-.242 * * *$ \\
\hline \multirow{5}{*}{ Definition } & Study 1 & $-.291 * * *$ & & & & & \\
\hline & Study 2 & $-.254 * * *$ & & & & & \\
\hline & Study 3 & & $.224 * * *$ & $.173 * * *$ & & & \\
\hline & Study 4 & $-.264 * * *$ & $.317 * * *$ & $.240^{*}$ & $-.230 * * *$ & $.223^{*}$ & \\
\hline & Study 5 & & & & & & $.376 * * *$ \\
\hline Centrality & Study 6 & $-.090 * * *$ & $.161 * * *$ & $.201 * * *$ & & & $.256 * * *$ \\
\hline
\end{tabular}




\section{Studies 7-10: Men}

Table 6 presents descriptive statistics, Table 7 presents the correlations, and Table 8 presents the regression coefficients in the analyses that tested the relation between gender identity measures and well-being measures (see the Appendix for full results of the multiple regression analyses). The men showed a similar pattern to the one found with women: In the multiple regression analysis, stronger gender acceptance, ingroup affect, gender typicality, and ingroup ties predicted better well-being. In contrast, stronger gender definition and centrality usually predicted worse well-being (As detailed in Table S12 in the online supplement, the strength of the relations between gender identity and well-being was not consistently stronger or weaker among men, in comparison to women).

Specifically, Studies 7 and 9 found similar relations between gender identity and selfesteem. In Study 7 , whereas gender typicality $(\beta=.148)$ and gender acceptance $(\beta=.467)$ predicted higher self-esteem, gender definition $(\beta=-.120, p=.008)$ predicted lower selfesteem. In Study 9, ingroup ties $(\beta=.160)$ and ingroup affect $(\beta=.328)$ predicted higher selfesteem, whereas centrality $(\beta=-.101, p=.008)$ predicted lower self-esteem.

The results for self-objectification in Studies 7 and 9 were similar to those found with self-esteem. In Study 7, gender typicality $(\beta=-.129)$ and gender acceptance $(\beta=-.280)$ predicted weaker self-objectification, whereas gender definition $(\beta=.277)$ predicted stronger self-objectification. In Study 9, ingroup ties $(\beta=-.169)$ predicted weaker self-objectification, ingroup affect $(\beta=-.082, p=.068)$ did not reliably predict self-objectification, and centrality $(\beta=.243)$ predicted stronger self-objectification.

In Studies 8 and 10, proneness to shame and guilt showed a slightly different pattern of results, but still replicated the central finding in the multiple regression: Gender definition and centrality were related to lower well-being (greater proneness to shame and guilt). In Study 8 , gender typicality marginally predicted lower proneness to shame $(\beta=-.093, p=$ 
$.050)$, gender acceptance predicted lower proneness to shame $(\beta=-.252)$, and gender definition predicted higher proneness to shame $(\beta=.110, p=.027)$. In addition, gender typicality $(\beta=-.157)$ and gender acceptance $(\beta=-.199)$ predicted lower proneness to guilt, whereas gender definition was not related, but trended to a positive relation $(\beta=.095, p=$ .058) with proneness to guilt. In Study 10, ingroup ties and ingroup affect predicted lower proneness to shame (ties: $\beta=-.142$; affect: $\beta=-.166$ ) and guilt (ties: $\beta=-.077, p=.078$; affect: $\beta=-.223)$, and centrality predicted higher proneness to shame $(\beta=.158)$ and guilt $(\beta=$ $.194)$.

Studies 8 and 10 also showed a slightly different pattern for the relations between gender identity and life satisfaction. The main finding was clearly replicated in Study 8, but less clearly in Study 10 (gender centrality was unrelated to life satisfaction). In Study 8, whereas gender typicality $(\beta=.232)$ and gender acceptance $(\beta=.274)$ predicted higher life satisfaction, gender definition $(\beta=-.110, p=.022)$ predicted lower life satisfaction. In Study 10 , ingroup ties $(\beta=.157)$ and ingroup affect $(\beta=.192)$ predicted greater life satisfaction, whereas centrality $(\beta=-.037, p=.348)$ did not reliably predict life satisfaction. 
Table 6

Studies 7-10 (Men): Mean (SD) and Cronbach's Alpha of the Main Variables

\begin{tabular}{|c|c|c|c|c|c|c|c|c|}
\hline \multirow[t]{2}{*}{ Study } & \multicolumn{3}{|c|}{ Gender Identity Facets } & \multirow[t]{2}{*}{ Self-esteem } & \multirow[t]{2}{*}{ Shame } & \multirow[t]{2}{*}{ Guilt } & \multirow[t]{2}{*}{ Life satisfaction } & \multirow[t]{2}{*}{ Self-objectification } \\
\hline & Typicality & Acceptance & Definition & & & & & \\
\hline 7 & $4.283(1.206)$ & $4.664(0.835)$ & $3.163(1.036)$ & $3.142(0.512)$ & & & & $3.542(0.876)$ \\
\hline$\alpha$ & .849 & .866 & .876 & .885 & & & & .855 \\
\hline 8 & $4.269(1.204)$ & $4.678(0.855)$ & $3.168(1.043)$ & & $2.118(0.584)$ & $2.316(0.746)$ & $4.775(1.320)$ & \\
\hline \multirow[t]{2}{*}{$\alpha$} & .838 & .870 & .878 & & .816 & .804 & .867 & \\
\hline & Ingroup ties & Ingroup affect & Centrality & & & & & \\
\hline 9 & $4.010(0.977)$ & $4.911(0.787)$ & $3.359(1.007)$ & $3.119(0.554)$ & & & & $3.571(0.964)$ \\
\hline$\alpha$ & .780 & .745 & .688 & .893 & & & & .879 \\
\hline 10 & $4.061(0.951)$ & $4.936(0.746)$ & $3.366(0.982)$ & & $2.158(0.635)$ & $2.321(0.751)$ & $4.774(1.293)$ & \\
\hline$\alpha$ & .785 & .720 & .654 & & .849 & .835 & .865 & \\
\hline
\end{tabular}


Table 7

Studies 7-10 (Men): Zero-Order Correlations Between Gender Identity and Well-Being

\begin{tabular}{|c|c|c|c|c|c|c|}
\hline & & $\begin{array}{l}\text { Self- } \\
\text { esteem }\end{array}$ & Shame & Guilt & $\begin{array}{l}\text { Life } \\
\text { satisfaction }\end{array}$ & $\begin{array}{l}\text { Self- } \\
\text { objectification }\end{array}$ \\
\hline \multirow[t]{2}{*}{ Typicality } & Study 7 & $.316^{* * *}$ & & & & $-.139 * *$ \\
\hline & Study 8 & & $-.163 * * *$ & $-.209 * * *$ & $.313 * * *$ & \\
\hline \multirow{2}{*}{ Ingroup ties } & Study 9 & $.301 * * *$ & & & & $-.185 * * *$ \\
\hline & Study 10 & & $-.211 * * *$ & $-.171 * * *$ & $.243 * * *$ & \\
\hline \multirow[t]{2}{*}{ Acceptance } & Study 7 & $.476 * * *$ & & & & $-.201 * * *$ \\
\hline & Study 8 & & $-.235^{* * *}$ & $-.221 * * *$ & $.323 * * *$ & \\
\hline \multirow[t]{2}{*}{ Ingroup affect } & Study 9 & $.382 * * *$ & & & & $-.115 * *$ \\
\hline & Study 10 & & $-.198 * * *$ & $-.218 * * *$ & $.256 * * *$ & \\
\hline \multirow[t]{2}{*}{ Definition } & Study 7 & $.180 * * *$ & & & & .079 \\
\hline & Study 8 & & -.069 & $-.084 *$ & $.143 * * *$ & \\
\hline \multirow[t]{2}{*}{ Centrality } & Study 9 & -.026 & & & & $.213 * * *$ \\
\hline & Study 10 & & $.118 * *$ & $.145^{* * *}$ & .009 & \\
\hline
\end{tabular}

Note. $* * * p<.001 ; * * p<.01 ; * p<.05$.

Table 8

Studies 7-10 (Men): Coefficients of Multiple Regression Analyses

\begin{tabular}{|c|c|c|c|c|c|c|}
\hline & & $\begin{array}{l}\text { Self- } \\
\text { esteem }\end{array}$ & Shame & Guilt & $\begin{array}{l}\text { Life } \\
\text { satisfactio } \\
\mathrm{n}\end{array}$ & $\begin{array}{l}\text { Self- } \\
\text { objectificatio } \\
\mathrm{n}\end{array}$ \\
\hline \multirow{2}{*}{ Typicality } & \multirow{2}{*}{$\begin{array}{l}\text { Study } 7 \\
\text { Study } 8\end{array}$} & $.148 * * *$ & & & & $-.129 * *$ \\
\hline & & & -.093 & $-.157 * * *$ & $.232 * * *$ & \\
\hline \multirow{2}{*}{ Ingroup ties } & \multirow{2}{*}{$\begin{array}{l}\text { Study } 9 \\
\text { Study } 10\end{array}$} & $.160 * * *$ & & & & $-.169 * * *$ \\
\hline & & & $-.142 * *$ & -.077 & $.157 * * *$ & \\
\hline \multirow{2}{*}{ Acceptance } & \multirow{2}{*}{$\begin{array}{l}\text { Study } 7 \\
\text { Study } 8\end{array}$} & $.467 * * *$ & & & & $-.280 * * *$ \\
\hline & & & $-.252 * * *$ & $-.199 * * *$ & $.274 * * *$ & \\
\hline \multirow{2}{*}{$\begin{array}{l}\text { Ingroup } \\
\text { affect }\end{array}$} & \multirow{2}{*}{$\begin{array}{l}\text { Study } 9 \\
\text { Study } 10\end{array}$} & $.328 * * *$ & & & & -.082 \\
\hline & & & $-.166 * * *$ & $-.223 * * *$ & $.192 * * *$ & \\
\hline \multirow{2}{*}{ Definition } & \multirow{2}{*}{$\begin{array}{l}\text { Study } 7 \\
\text { Study } 8 \\
\end{array}$} & $-.120 * *$ & & & & $.277 * * *$ \\
\hline & & & $.110 *$ & .095 & $-.110 *$ & \\
\hline \multirow{2}{*}{ Centrality } & \multirow{2}{*}{$\begin{array}{l}\text { Study } 9 \\
\text { Study } 10\end{array}$} & $-.101 * *$ & & & & $.243 * * *$ \\
\hline & & & $.158 * * *$ & $.194 * * *$ & -.037 & \\
\hline
\end{tabular}




\section{Discussion}

Ten correlational studies found that there are facets of gender identity that are consistently positively related to people's reported well-being, whereas other facets are usually negatively related to well-being. Gender identity was a positive predictor of wellbeing when it pertained to people's feelings toward their gender and their sense of belongingness and assimilation into their gender group. The more positive people felt about their gender and their fit with their gender group, the better their well-being was. In contrast, the centrality and importance of gender in people's identity had a negative relation with wellbeing, with stronger centrality and importance predicting lower well-being. We found this pattern mostly in multiple regression analyses, after controlling for the shared variance between the various gender identity facets. The results were quite consistent and robust among both genders, strongly generalized by using two different sets of gender identity measures and six well-being variables.

The positive relations between well-being and people's feelings toward their gender and their sense of belongingness and assimilation into their gender group are in line with theories that describe belongingness as a basic need that, when fulfilled, promotes well-being (Baumeister \& Leary, 1995) or as a mechanism that protects one's well-being when one experiences rejection from an outgroup (Branscombe et al., 1999).

The negative relation between women's well-being and gender identity centrality fits the theoretical perspective that attribute the relation between group identity and well-being to the social status of the group (e.g., Gentile et al., 2009; Major et al., 2002; Tajfel \& Turner, 1979). Perhaps centrality was negative for women because it reflects the salience of being a member of a disadvantaged group (Major et al., 2002, 2003). If the social status of women explains our results, then women's perception of gender inequality might mediate the 
relations we found between gender centrality and well-being ${ }^{1}$. In Study 11 and 13, we tested this possibility by measuring women's perception that women are oppressed, and that they have personally suffered gender-based discrimination.

Because men belong to the high-status group, some theories would expect that men's gender identity centrality would be positively related with well-being (Gentile et al., 2009; Tajfel \& Turner, 1979). Why was gender centrality negatively related to well-being among men? We tested several accounts in Studies 12 and 14. One possible reason for these results is that men do not perceive their group as privileged and might even believe that there is antimen discrimination (Kobrynowicz \& Branscombe, 1997). Alternatively, men might feel guilt for being privileged (Case, 2007). In both cases, centrality of gender identity might make one more aware of their gender's social status and the negative ramifications of that status, and therefore might harm one's well-being. A third possibility is related to the notion that manhood is a set of gender-role expectations to which men are constantly pressured to conform, under the threat of losing their status as men or as the advantaged gender group (Vandello \& Bosson, 2013). This possibility might also be relevant for women, who experience pressure to conform with the feminine role (Mahalik et al., 2005). Centrality of gender identity might signal that one is constantly aware of those demands, which in turn might cause stress and harm one's well-being.

Finally, we also tested the possibility that low gender centrality could be a sign of high self-complexity (Linville, 1985, 1987) - having multiple distinct aspects in one's identity. Multiple social identities improve self-regulation, which might have a positive effect on well-being. Perhaps gender is more central among those whose social identity does not

\footnotetext{
${ }^{1}$ We thank an anonymous reviewer for proposing this mediator.
} 
possess multiple aspects, and that lack of self-complexity is the reason for lower well-being, regardless of the group's social status. In Studies 11-14, we investigated all these possible mechanisms, by deriving from each explanation a possible mediator for the relation between gender centrality and well-being.

\section{Studies 11-14}

The studies used a correlational design to examine the statistical plausibility of a few variables as mediators of the negative relation between gender centrality and well-being. The variables were perception of gender inequality, perception of pressure to conform to genderrole expectations, and social identity complexity. Studies 11 (women) and 13 (men) used one set of gender identity measures, replicated with a different set in Studies 12 (women) and 14 (men).

\section{Method}

All the materials and data files for Studies 11-14 are available online at anonymized link. Each study included three measures of gender identity facets, a few measures of potential mediators, and two measures of well-being (see Table 9). Of the various well-being measures used in the previous studies, we chose the two that most consistently replicated the pattern of results in the multiple regression analyses - self-esteem and depressive symptoms. We replaced the relatively long measure of depressive symptoms (used in Study 4) with a shorter measure, which was more appropriate for Internet studies.

Perception of gender inequality included a measure of perception of the status of one's gender group (female oppression in the women samples and male privilege in the men samples), and a measure of perception of personal gender-based discrimination (same measure for men and women). An additional measure of male guilt was included in Studies 12 and 14. Perception of pressure to conform to gender-role expectations was measured with a measure of femininity expectations in the women samples and a measure of masculinity 
expectations in the men samples. Each of the studies also included a measure unrelated to the present research (full details at anonymized link).

\section{Participants}

Participants in these studies were women (Studies 11 and 13) and men (Studies 12 and 14) volunteers at Project Implicit website. The dates of Studies 11 and 12 overlapped. The dates of Studies 13 and 14 overlapped. The analyses included participants who completed all the questionnaires (see Table 9 for details).

\section{Procedure}

Participants first completed the gender identity questionnaires (in a random order), followed by measures of perception of gender inequality, perception of pressure to conform to gender-role expectations, and social identity complexity (in a random order). Finally, they completed the well-being measures (in a random order).

\section{Measures}

Table 10 displays the internal consistency of all the measures. Unless specified otherwise, the score of each measure was the mean response of all the items. Unless specified otherwise, the response scale in all the measures of the potential mediating variables were on a 1-6 agreement scale.

Gender Identity. The gender identity measures were identical to those used in Studies 1-10.

\section{Perception of Gender Inequality.}

Perception of Gender Status. Among women, we measured the perception of gender status with four items from the Gender Discrimination scale (Kobrynowicz \& Branscombe, 1997), two from the Gender Issues Survey (Sipe et al., 2009), and two from the Male Privilege Awareness scale (Case, 2007). Male participants completed the 7-item Male 
Privilege Awareness scale (Case, 2007), assessing perception of gender status (e.g., Men have privileges that women do not have).

Perception of Personal Gender-Based Discrimination. The 6-item Past Experience with Gender Discrimination scale (Schmitt et al., 2002) assessed perception of personal gender-based discrimination (e.g., I feel like I am personally a victim of society because of my gender).

Male Guilt. Men completed this measure (e.g., I feel guilty about the past and present social gender inequality): six items from the White Guilt scale (Swim \& Miller, 1999), two items from the Group-based Guilt scale (Boeckmann \& Feather, 2007), and two items that we created to make sure we capture the type of guilt we had in mind.

Gender-Role Expectations. Women completed the Beliefs About Women scale (Snell \& Godwin, 2013) to assess perceived pressure to conform to feminine-role expectations (e.g., Women should be less career interested than men). We slightly modified some of the items so they would reflect perceived expectations of women instead of stereotypes. Men completed the Male Role Norms Inventory - short form (Levant et al., 2013) to assess the perceived pressure to conform to masculine-role expectations with 15 items (e.g., Men should be detached in emotionally charged situations). We used the five most relevant subscales (out of seven) and modified a few of the items so they would reflect perceived expectations of men instead of beliefs about norms.

Social Identity Complexity. Based on self-complexity theory (Linville, 1985), we created a measure to capture social identity complexity with two items. First, participants selected all the groups (e.g., religious group, political group, social class group) that were important to their identity out of nine possible options. The score for the first item was the number of selected groups. Second, participants indicated how many identities they perceive as important to them, with a response scale ranging from "1" to "10 or more" (coded as 10). 
The mean of these two items was the score (higher scores indicate greater social identity complexity).

\section{Well-Being.}

Self-Esteem. This measure was identical to the one used in the prior set of studies.

Depressive Symptoms. The Patient Health Questionnaire depression module (Kroenke et al., 2001) assessed depressive symptoms severity with a 9-item questionnaire, in which participants rated depressive symptoms in the past two weeks on a 0-to-3 severity scale. Depression scores were a sum of all items (higher scores indicate more severe depression).

\section{Results}

Due to poor reliability of the social identity complexity measure (Cronbach's $\alpha=$ $.566, .584, .605, .548$ in Studies 11, 12, 13, and 14, respectively), the (uninformative) results of all analyses that involve this measure are reported only in the supplemental materials.

\section{Relations Between Gender Identity and Well-Being}

Table 10 presents descriptive statistics of all of the variables. Table 11 presents the regression coefficients in the analyses that tested the relations between gender identity measures and well-being measures across the four studies (see the Appendix for full results of the multiple regression analyses and inter-correlations). As in Studies 1-10, the multiple regression analyses found that whereas stronger gender acceptance, ingroup affect, gender typicality, and ingroup ties predicted better well-being, stronger gender definition and centrality predicted worse well-being. The one exception was in Study 13: Women's gender centrality had no relation with depressive symptoms. 
Table 9

Studies 11-14: Demographics and Main Variables

\begin{tabular}{|c|c|c|c|c|c|c|c|c|c|}
\hline Study & $N$ & Gender & $\begin{array}{l}\text { Mean age } \\
(S D)\end{array}$ & $\%$ White & $\%$ USA & $\begin{array}{l}\text { Gender } \\
\text { identity Facets }\end{array}$ & $\begin{array}{l}\text { Well-being } \\
\text { variables }\end{array}$ & Potential Mediators & $\begin{array}{l}\text { Excluded participants } \\
\text { due to missing data }\end{array}$ \\
\hline 11 & 537 & $\mathrm{f}$ & $32.0(13.9)$ & 71.1 & 76.1 & $\begin{array}{l}\text { Typicality, } \\
\text { acceptance, } \\
\text { definition }\end{array}$ & $\begin{array}{l}\text { Self-esteem } \\
\text { and } \\
\text { depressive } \\
\text { symptoms }\end{array}$ & $\begin{array}{l}\text { Perceived gender status, perceived } \\
\text { personal gender-based discrimination, } \\
\text { perceived gender-role expectations, } \\
\text { social identity complexity }\end{array}$ & 29 \\
\hline 12 & 564 & $\mathrm{~m}$ & $33.6(14.5)$ & 65.6 & 66.4 & $\begin{array}{l}\text { Typicality, } \\
\text { acceptance, } \\
\text { definition }\end{array}$ & $\begin{array}{l}\text { Self-esteem } \\
\text { and } \\
\text { depressive } \\
\text { symptoms }\end{array}$ & $\begin{array}{l}\text { Perceived gender status, perceived } \\
\text { personal gender-based discrimination, } \\
\text { perceived gender-role expectations, } \\
\text { male guilt, social identity complexity }\end{array}$ & 42 \\
\hline 13 & 603 & $\mathrm{f}$ & $31.6(13.6)$ & 68.8 & 76.4 & $\begin{array}{l}\text { Ingroup ties, } \\
\text { ingroup affect, } \\
\text { centrality }\end{array}$ & $\begin{array}{l}\text { Self-esteem } \\
\text { and } \\
\text { depressive } \\
\text { symptoms }\end{array}$ & $\begin{array}{l}\text { Perceived gender status, perceived } \\
\text { personal gender-based discrimination, } \\
\text { perceived gender-role expectations, } \\
\text { social identity complexity }\end{array}$ & 34 \\
\hline 14 & 538 & $\mathrm{~m}$ & $33.2(14.9)$ & 67.6 & 70.1 & $\begin{array}{l}\text { Ingroup ties, } \\
\text { ingroup affect, } \\
\text { centrality }\end{array}$ & $\begin{array}{l}\text { Self-esteem } \\
\text { and } \\
\text { depressive } \\
\text { symptoms }\end{array}$ & $\begin{array}{l}\text { Perceived gender status, perceived } \\
\text { personal gender-based discrimination, } \\
\text { perceived gender-role expectations, } \\
\text { male guilt, social identity complexity }\end{array}$ & 52 \\
\hline
\end{tabular}

Note. \% USA refers to the percentage of USA resident (self-reported); This table does not include the exploratory measures that were unrelated to the present research question. 
Table 10

Studies 11-14: Mean (SD) and Cronbach's Alpha of the Main Variables

\begin{tabular}{|c|c|c|c|c|c|c|c|c|c|c|}
\hline \multirow[t]{2}{*}{ Study } & Gender & \multicolumn{3}{|c|}{ Gender Identity Facets } & \multirow[t]{2}{*}{ Gender Status } & \multirow[t]{2}{*}{$\begin{array}{c}\text { Personal } \\
\text { discrimination }\end{array}$} & \multirow[t]{2}{*}{ Male guilt } & \multirow[t]{2}{*}{$\begin{array}{l}\text { Gender-role } \\
\text { expectations }\end{array}$} & \multirow[t]{2}{*}{ Self-esteem } & \multirow{2}{*}{$\begin{array}{l}\text { Depressive } \\
\text { symptoms }\end{array}$} \\
\hline & & Typicality & Acceptance & Definition & & & & & & \\
\hline \multirow[t]{2}{*}{11} & $\mathrm{f}$ & $4.331(1.202)$ & $4.935(0.822)$ & $3.780(1.074)$ & $4.368(0.938)$ & $3.441(1.190)$ & & 2.778 (1.129) & $3.018(0.549)$ & $7.385(5.521)$ \\
\hline & $\alpha$ & .853 & .887 & .879 & .897 & .874 & & .938 & .901 & .872 \\
\hline \multirow[t]{3}{*}{12} & $\mathrm{~m}$ & $4.363(1.243)$ & $4.708(0.849)$ & $3.272(1.068)$ & $4.010(1.050)$ & $2.158(0.917)$ & 3.485 (1.039) & $2.870(0.850)$ & $3.050(0.516)$ & $6.222(5.264)$ \\
\hline & $\alpha$ & .852 & .881 & .877 & .872 & .799 & .900 & .920 & .868 & .867 \\
\hline & & Ingroup ties & Ingroup affect & Centrality & & & & & & \\
\hline \multirow[t]{2}{*}{13} & $\mathrm{f}$ & $4.449(0.963)$ & $5.173(0.748)$ & $4.092(0.980)$ & $4.455(0.872)$ & $3.353(1.173)$ & & $2.802(1.091)$ & $2.996(0.542)$ & $7.177(5.625)$ \\
\hline & $\alpha$ & .811 & .803 & .680 & .887 & .861 & & .928 & .887 & .877 \\
\hline \multirow[t]{2}{*}{14} & $\mathrm{~m}$ & $4.126(0.987)$ & $4.913(0.790)$ & $3.446(0.943)$ & $4.010(1.086)$ & $2.124(0.897)$ & $3.471(0.970)$ & $2.807(0.855)$ & $3.306(0.579)$ & $6.186(5.297)$ \\
\hline & $\alpha$ & .783 & .745 & .583 & .877 & .788 & .884 & .924 & .896 & .870 \\
\hline
\end{tabular}


Table 11

Studies 11-14: Coefficients of Multiple Regression Analyses

\begin{tabular}{lllll}
\hline & & Gender & Self-esteem & $\begin{array}{l}\text { Depressive } \\
\text { symptoms }\end{array}$ \\
\hline \multirow{2}{*}{ Typicality } & Study 11 & $\mathrm{f}$ & $.065(.150)$ & $-.099^{*}$ \\
& Study 12 & $\mathrm{m}$ & $.106^{*}$ & $-.147^{* *}$ \\
\hline \multirow{2}{*}{ Ingroup ties } & Study 13 & $\mathrm{f}$ & $.116^{* *}$ & $-.096^{*}$ \\
& Study 14 & $\mathrm{m}$ & $.236^{* * *}$ & $-.247^{* * *}$ \\
\hline \multirow{2}{*}{ Acceptance } & Study 11 & $\mathrm{f}$ & $.455^{* * *}$ & $-.188^{* * *}$ \\
& Study 12 & $\mathrm{m}$ & $.465^{* * *}$ & $-.157^{* *}$ \\
\hline \multirow{2}{*}{ Ingroup affect } & Study 13 & $\mathrm{f}$ & $.358^{* * *}$ & $-.154^{* * *}$ \\
& Study 14 & $\mathrm{m}$ & $.347^{* * *}$ & $-.081(.087)$ \\
\hline \multirow{2}{*}{ Definition } & Study 11 & $\mathrm{f}$ & $-.201^{* * *}$ & $.144^{*}$ \\
& Study 12 & $\mathrm{m}$ & $-.162^{* * *}$ & $.118^{*}$ \\
\hline \multirow{2}{*}{ Centrality } & Study 13 & $\mathrm{f}$ & $-.101^{* *}$ & $.061(.142)$ \\
& Study 14 & $\mathrm{m}$ & $-.144^{* * *}$ & $.171^{* * *}$ \\
\hline
\end{tabular}

Notes. $* * * p<.001 ; * * p<.01 ; * p<.05$. As detailed in Table

$\mathrm{S} 17$ in the online supplement, the strength of the relations between gender identity and well-being was not consistently stronger or weaker in one gender, in comparison to the other.

\section{Mediation Analyses}

We conducted the mediation analyses with the R package Lavaan (Rosseel, 2012).

We entered the gender identity facets as predictors and well-being (self-esteem or depressive symptoms) as the dependent variable. We conducted a separate analysis for each potential mediating variable. We entered the mediating variables as mediators for the relations between all three gender identity facets and well-being, although we were only interested in examining their mediating role in the relation between gender definition/centrality and well-being, to control for the covariance between the mediating variables and the non-focal gender identity facets.

Unstandardized regression coefficients were computed for each path in the mediation model, but we report only the paths of the mediation between gender definition/centrality and well-being. Path $a$ represents the effect of gender definition/centrality on the mediator; path $b$ represents the effect of the mediator on well-being; path $c$ represents the total effect of gender 
definition/centrality on well-being; path $c^{\prime}$ represents the direct effect of gender definition/centrality on well-being, partialling out the effect of the mediator. Importantly, we calculated the indirect effect (i.e., the mediation effect) as the product of path $a$ and path $b$. In the present correlational design, "effects" is used for relations, rather than real causal effects.

Studies 11 and 13 (Women). Perceived gender status consistently mediated the relation between centrality and well-being (self-esteem: $b=-0.014, S E=0.007, \mathrm{CI}[-0.028$, 0.001]; depressive symptoms: $b=0.271, S E=0.082$, CI [0.111, 0.431]), but did not significantly mediate the relation between gender definition and well-being (self-esteem: $b=$ $-0.003, S E=0.003, \mathrm{CI}[-0.009,0.002]$; depressive symptoms: $b=0.079, S E=0.051, \mathrm{CI}[-$ $0.022,0.179])$.

Perceived personal gender-based discrimination consistently mediated the relation between centrality and well-being (self-esteem: $b=-0.015, S E=0.008$, CI $[-0.031,-0.000]$; depressive symptoms: $b=0.406, S E=0.095$, CI [0.220, 0.591]), and also mediated the relation between gender definition and depressive symptoms $(b=0.131, S E=0.057, \mathrm{CI}$ $[0.019,0.243])$, but did not significantly mediate the relation between gender definition and self-esteem $(b=-0.005, S E=0.004$, CI $[-0.012,0.003])$.

There was no evidence that perceived pressure to conform to gender-role expectations had any mediating role (Table 12).

Studies 12 and 14 (Men). Perceived pressure to conform to gender-role expectations consistently mediated the relation between gender definition and well-being (self-esteem: $b=$ $-0.021, S E=0.008, \mathrm{CI}[-0.037,-0.006]$; depressive symptoms: $b=0.450, S E=0.100, \mathrm{CI}$ $[0.254,0.645])$ and the relation between centrality and well-being (self-esteem: $b=-0.021$, $S E=0.006$, CI [-0.033, -0.008]; depressive symptoms: $b=0.207, S E=0.065$, CI [0.080, 0.334]). There was no evidence that perceived gender status, perceived personal gender-based discrimination, or male guilt had any mediating role (Table 13). 
Table 12

Studies 11 and 13 (Women): Mediation Effects

\begin{tabular}{|c|c|c|c|c|c|c|c|c|}
\hline Mediator & $\begin{array}{l}\text { Gender } \\
\text { identity facet }\end{array}$ & Well-being & Study & $\begin{array}{c}\text { Path a } \\
b, p\end{array}$ & $\begin{array}{c}\text { Path b } \\
b, p\end{array}$ & $\begin{array}{l}\text { Total effect (c) } \\
\qquad b, p\end{array}$ & $\begin{array}{l}\text { Direct effect (c') } \\
\qquad b, p\end{array}$ & $\begin{array}{c}\text { Indirect effect }(\mathrm{a} * \mathrm{~b}) \\
b(S E)[1-\mathrm{ci}, \mathrm{u}-\mathrm{ci}]\end{array}$ \\
\hline \multirow{4}{*}{$\begin{array}{l}\text { Perceived } \\
\text { gender status }\end{array}$} & Definition & Self-esteem & 11 & $0.083, .095$ & $-0.038, .100$ & $-0.103,<.001$ & $-0.100,<.001$ & $-0.003(0.003)[-0.009,0.002]$ \\
\hline & Centrality & & 13 & $0.275,<.001$ & $-0.052, .030$ & $-0.056, .009$ & $-0.042, .061$ & $-0.014(0.007)[-0.028,-0.001]$ \\
\hline & Definition & Depressive & 11 & $0.083, .095$ & $0.947,<.001$ & $0.741, .010$ & $0.663, .021$ & $0.079(0.051)[-0.022,0.179]$ \\
\hline & Centrality & symptoms & 13 & $0.275,<.001$ & $0.987,<.001$ & $0.353, .140$ & $0.082, .741$ & $0.271(0.082)[0.111,0.431]$ \\
\hline \multirow{4}{*}{$\begin{array}{l}\text { Perceived } \\
\text { personal } \\
\text { gender-based } \\
\text { discrimination }\end{array}$} & Definition & Self-esteem & 11 & $0.188, .002$ & $-0.024, .200$ & $-0.103,<.001$ & $-0.098,<.001$ & $-0.005(0.004)[-0.012,0.003]$ \\
\hline & Centrality & & 13 & $0.406,<.001$ & $-0.038, .040$ & $-0.056, .009$ & $-0.041, .071$ & $-0.015(0.008)[-0.031,-0.000]$ \\
\hline & Definition & Depressive & 11 & $0.188, .002$ & $0.697,<.001$ & $0.741, .010$ & $0.610, .035$ & $0.131(0.057)[0.019,0.243]$ \\
\hline & Centrality & symptoms & 13 & $0.406,<.001$ & $0.998,<.001$ & $0.353, .140$ & $-0.053, .831$ & $0.406(0.095)[0.220,0.591]$ \\
\hline \multirow{4}{*}{$\begin{array}{l}\text { Perceived } \\
\text { gender-role } \\
\text { expectations }\end{array}$} & Definition & Self-esteem & 11 & $0.139, .020$ & $-0.061, .002$ & $-0.103,<.001$ & $-0.095,<.001$ & $-0.008(0.005)[-0.017,0.000]$ \\
\hline & Centrality & & 13 & $0.230,<.001$ & $-0.025, .186$ & $-0.056, .009$ & $-0.050, .021$ & $-0.006(0.004)[-0.015,0.003]$ \\
\hline & Definition & Depressive & 11 & $0.139, .020$ & $0.564, .007$ & $0.741, .010$ & $0.663, .022$ & $0.078(0.044)[-0.009,0.165]$ \\
\hline & Centrality & symptoms & 13 & $0.230,<.001$ & $0.338, .109$ & $0.353, .140$ & $0.275, .258$ & $0.078(0.051)[-0.022,0.177]$ \\
\hline
\end{tabular}


Table 13

Studies 12 and 14 (Men): Mediation Effects

\begin{tabular}{|c|c|c|c|c|c|c|c|c|}
\hline Mediator & $\begin{array}{l}\text { Gender } \\
\text { identity facet }\end{array}$ & Well-being & Study & $\begin{array}{c}\text { Path a } \\
b, p\end{array}$ & $\begin{array}{c}\text { Path b } \\
b, p\end{array}$ & $\begin{array}{c}\text { Total effect (c) } \\
b, p\end{array}$ & $\begin{array}{c}\text { Direct effect (c') } \\
\qquad b, p\end{array}$ & $\begin{array}{c}\text { Indirect effect }\left(\mathrm{a}^{*} \mathrm{~b}\right) \\
b(S E)[1-\mathrm{ci}, \mathrm{u}-\mathrm{ci}]\end{array}$ \\
\hline \multirow{4}{*}{$\begin{array}{l}\text { Perceived } \\
\text { gender status }\end{array}$} & Definition & Self-esteem & 12 & $-0.148, .003$ & $-0.013, .498$ & $-0.078, .001$ & $-0.080,<.001$ & $0.002(0.003)[-0.004,0.008]$ \\
\hline & Centrality & & 14 & $0.012, .802$ & $0.012, .558$ & $-0.089,<.001$ & $-0.089,<.001$ & $0.000(0.001)[-0.001,0.001]$ \\
\hline & Definition & Depressive & 12 & $-0.148, .003$ & $0.201, .350$ & $0.583, .022$ & $0.613, .017$ & $-0.030(0.033)[-0.095,0.036]$ \\
\hline & Centrality & symptoms & 14 & $0.012, .802$ & $-0.404, .050$ & $0.961,<.001$ & $0.966,<.001$ & $-0.005(0.020)[-0.044,0.034]$ \\
\hline \multirow{4}{*}{$\begin{array}{l}\text { Perceived } \\
\text { personal } \\
\text { gender-based } \\
\text { discrimination }\end{array}$} & Definition & Self-esteem & 12 & $0.075, .093$ & $-0.080,<.001$ & $-0.078, .001$ & $-0.072, .001$ & $0.006(0.004)[-0.014,0.002]$ \\
\hline & Centrality & & 14 & $0.065, .114$ & $-0.029, .244$ & $-0.089,<.001$ & $-0.087,<.001$ & $-0.002(0.002)[-0.006,0.002]$ \\
\hline & Definition & Depressive & 12 & $0.075, .093$ & $1.312,<.001$ & $0.583, .022$ & $0.484, .051$ & $0.099(0.061)[-0.021,0.219]$ \\
\hline & Centrality & symptoms & 14 & $0.065, .114$ & $0.881,<.001$ & $0.961,<.001$ & $0.904,<.001$ & $0.057(0.039)[-0.020,0.134]$ \\
\hline \multirow{4}{*}{ Male guilt } & Definition & Self-esteem & 12 & $-0.117, .018$ & $-0.020, .309$ & $-0.078, .001$ & $-0.081,<.001$ & $0.002(0.002)[-0.003,0.007]$ \\
\hline & Centrality & & 14 & $0.098, .022$ & $-0.017, .467$ & $-0.089,<.001$ & $-0.087,<.001$ & $-0.002(0.002)[-0.006,0.003]$ \\
\hline & Definition & Depressive & 12 & $-0.117, .018$ & $0.256, .239$ & $0.583, .022$ & $0.613, .016$ & $-0.030(0.028)[-0.085,0.026]$ \\
\hline & Centrality & symptoms & 14 & $0.098, .022$ & $0.082, .728$ & $0.961,<.001$ & $0.953,<.001$ & $0.008(0.023)[-0.038,0.054]$ \\
\hline \multirow{4}{*}{$\begin{array}{l}\text { Perceived } \\
\text { gender-role } \\
\text { expectations }\end{array}$} & Definition & Self-esteem & 12 & $0.307,<.001$ & $-0.070, .004$ & $-0.078, .001$ & $-0.057, .017$ & $-0.021(0.008)[-0.037,-0.006]$ \\
\hline & Centrality & & 14 & $0.196,<.001$ & $-0.105,<.001$ & $-0.089,<.001$ & $-0.068,<.001$ & $-0.021(0.006)[-0.033,-0.008]$ \\
\hline & Definition & Depressive & 12 & $0.307,<.001$ & $1.466,<.001$ & $0.583, .022$ & $0.133, .610$ & $0.450(0.100)[0.254,0.645]$ \\
\hline & Centrality & symptoms & 14 & $0.196,<.001$ & $1.056,<.001$ & $0.961,<.001$ & $0.754, .001$ & $0.207(0.065)[0.080,0.334]$ \\
\hline
\end{tabular}




\section{Discussion}

Study 13 found some evidence consistent with the possibility that gender centrality was negatively related to women's well-being because women perceive their gender as disadvantaged. Women with stronger gender centrality reported perceiving lower status for women in comparison to men and higher levels of personal gender-based discrimination. These perceptions were related to lower self-esteem and more depressive symptoms. However, the mediation effects were sometimes quite small, and were replicated in Study 11 only for depressive symptoms and not for self-esteem

Studies 12 and 14 found evidence consistent with the possibility that gender centrality and salience was negatively related to men's well-being because of perceived pressure to conform to the masculine role. Men who reported higher gender centrality and salience tended to report higher level of pressure to conform with the masculine gender-role, which predicted lower self-esteem and more depressive symptoms.

\section{General Discussion}

In the present research, we investigated the relations between various facets of gender identity and well-being. We tested the relations between two sets of gender identity facets and six measures of well-being in ten studies (Studies 1-10). The zero-order correlations showed a pattern of results that was very similar to the pattern found across previous studies (summarized in Table 1). Whereas assimilation in one's gender group and positive affect towards being a woman/man were usually positively related to well-being, the relations between gender centrality and well-being were inconsistent. Multiple regression analyses revealed a more consistent pattern of relations: The assimilation and affect facets had unique positive relations with well-being, whereas the centrality facet had a unique negative relation with well-being. These results were consistent among both genders. 
The positive relations between well-being and acceptance and belongingness are consistent with previous findings (e.g., Roszak, 2010). They are also consistent with the theoretical perspectives that propose that feelings of belongingness and bond with ingroup members and feeling positively towards group membership contributes positively to psychological well-being, among advantaged and disadvantaged groups alike (Baumeister \& Leary, 1995; Branscombe et al., 1999).

The main contribution of the present research is the finding of a consistent pattern of a negative relation between gender identity centrality and well-being, across two different sets of gender identity measures and six measures of well-being. This consistent pattern was previously obscured by the relation between gender centrality and other gender identity aspects. By controlling for this relation, we were able to uncover a clear negative aspect of gender identity centrality. Among women, the negative relation between identity centrality and well-being is consistent with theories such as the reflected appraisals model (e.g., Gentile et al., 2009), social identity theory (Tajfel \& Turner, 1979), and the discounting model (e.g., Major et al., 2002). These theories assume that centrality of a disadvantaged group in one's identity is harmful rather than beneficial. Indeed, in Study 13, we found that women who reported higher gender centrality also perceived larger gender inequality and reported higher levels of personal gender-based discrimination, which predicted worse well-being. These results suggest that the negative relation between gender centrality and well-being could be due to women's perception of their gender as disadvantaged. Note, however, that the validity of the mediation findings is limited by the correlational nature of the studies and by a failure to replicate them with an alternative set of gender identity measures (Study 11).

Other findings in our research, however, challenge a simplistic perspective that traces the negative relation between gender centrality and well-being only to group status and group derogation. Men, the higher-status gender, also showed a negative relation between gender 
centrality and well-being. This finding is intriguing, and inspires further theorization and research. We explored a few possible accounts in Studies 12 and 14, with initial support for one possibility. We found that perceived pressure to conform to the masculine gender-role mediated the relation between gender centrality and well-being. Men who reported greater gender centrality, reported perceiving higher levels of pressure to conform with the masculine gender-role, which predicted worse well-being. These results suggest that the negative relation between gender centrality and well-being might be due to men's perceived uncertainty of their status as "real" men, and perceived fragility of their advantaged status. This conclusion is compatible with the theory that manhood is a precarious and uncertain social status that must be earned and publicly demonstrated (Vandello \& Bosson, 2013).

Thus, the present research provides initial support for the possibility that the negative relation between gender centrality and well-being among both genders is due to the link between gender centrality and a perceived threat on one's social status. Among women, it reflects the perception that women are disadvantaged. Among men, it reflects the perception that although it is advantageous to be a man, men are under a constant threat of losing their membership in that high-status group.

\section{Limitations and Future Research}

The correlational nature of the present research prevents strong conclusions about causal relations. Indeed, previous research has provided support for alternative models of the relation between gender identity, well-being, and perception of discrimination (e.g., Branscombe et al., 1999; McCoy \& Major, 2003). These conflicting findings suggest that the relation between these constructs is complex and needs additional clarification. A major obstacle in investigating the relation between social identity and well-being is that both variables are not easily manipulated, limiting the investigation of their causal relations. Because social identity is a rather stable construct and its facets are related to one another, it 
might be challenging to develop accurate and strong manipulations of different social identity facets. Nevertheless, some studies have manipulated social identity (e.g., Jetten et al., 2001), or specific facets of social identity (e.g., Shih et al., 1999; Vial \& Napier, 2017). Such manipulations might be an important step towards better understanding of the casual relations between social identity and well-being and the mechanisms that underlie these relations among men and women. Another research design that might allow causal inference is longitudinal studies that would measure all the relevant variables over a long period of time (e.g., Ramos et al., 2012).

Another informative research direction would be repeating the present studies among members of other advantaged and disadvantaged groups. It would be informative to know whether disadvantaged ethnic groups show the same patterns as those found in the present research. If that is not the case, it would be an opportunity to uncover the difference between gender and ethnic groups in the processes that link social identity with well-being. 


\section{References}

Ashmore, R. D., Deaux, K., \& McLaughlin-Volpe, T. (2004). An Organizing Framework for Collective Identity: Articulation and Significance of Multidimensionality. Psychological Bulletin, 130(1), 80-114.

Baumeister, R. F., \& Leary, M. R. (1995). The need to belong: Desire for interpersonal attachments as a fundamental human motivation. Psychological Bulletin, 117(3), 497529.

Beck, A. T., Steer, R. A., \& Brown, G. (1996). Manual for the Beck Depression Inventory-II. San Antonio, TX: Psychological Corporation.

Boeckmann, R. J., \& Feather, N. T. (2007). Gender, Discrimination Beliefs, Group-Based Guilt, and Responses to Affirmative Action for Australian Women. Psychology of Women Quarterly, 31(3), 290-304.

Bourguignon, D., Seron, E., Yzerbyt, V., \& Herman, G. (2006). Perceived group and personal discrimination: Differential effects on personal self-esteem. European Journal of Social Psychology, 36(5), 773-789.

Branscombe, N. R., Schmitt, M. T., \& Harvey, R. D. (1999). Perceiving pervasive discrimination among African Americans: Implications for group identification and well-being. Journal of Personality and Social Psychology, 77(1), 135-149.

Busseri, M. A., \& Sadava, S. W. (2010). A Review of the Tripartite Structure of Subjective Well-Being: Implications for Conceptualization, Operationalization, Analysis, and Synthesis. Personality and Social Psychology Review, 15(3), 290-314.

Cameron, J. E. (2004). A Three-Factor Model of Social Identity. Self and Identity, 3(3), 239262. 
Casad, B. J., Hale, P., \& Wachs, F. L. (2017). Stereotype Threat Among Girls: Differences by Gender Identity and Math Education Context. Psychology of Women Quarterly, 41(4), $513-529$.

Case, K. A. (2007). Raising Male Privilege Awareness and Reducing Sexism: An Evaluation of Diversity Courses. Psychology of Women Quarterly, 31(4), 426-435.

Crabtree, J. W., Haslam, S. A., Postmes, T., \& Haslam, C. (2010). Mental Health Support Groups, Stigma, and Self-Esteem: Positive and Negative Implications of Group Identification. Journal of Social Issues, 66(3), 553-569.

Crocker, J., \& Major, B. (1989). Social stigma and self-esteem: The self-protective properties of stigma. Psychological Review, 96(4), 608-630.

Cruwys, T., Dingle, G. A., Hornsey, M. J., Jetten, J., Oei, T. P. S., \& Walter, Z. C. (2014). Social isolation schema responds to positive social experiences: Longitudinal evidence from vulnerable populations. British Journal of Clinical Psychology, 53(3), $265-280$.

Cruwys, T., \& Gunaseelan, S. (2016). "Depression is who I am”: Mental illness identity, stigma and wellbeing. Journal of Affective Disorders, 189, 36-42.

Dahl, J., Vescio, T., \& Weaver, K. (2015). How threats to masculinity sequentially cause public discomfort, anger, and ideological dominance over women. Social Psychology, $46(4), 242-254$.

Diener, E., Emmons, R. A., Larsen, R. J., \& Griffin, S. (1985). The Satisfaction With Life Scale. Journal of Personality Assessment, 49(1), 71-75.

Eccleston, C. P., \& Major, B. N. (2006). Attributions to Discrimination and Self-Esteem: The Role of Group Identification and Appraisals. Group Processes \& Intergroup Relations, 9(2), 147-162. 
Egan, S. K., \& Perry, D. G. (2001). Gender identity: A multidimensional analysis with implications for psychosocial adjustment. Developmental Psychology, 37(4), 451463.

Ellemers, N., Kortekaas, P., \& Ouwerkerk, J. W. (1999). Self-categorisation, commitment to the group and group self-esteem as related but distinct aspects of social identity. European Journal of Social Psychology, 29(2-3), 371-389.

Emerson, R. M. (1976). Social Exchange Theory. Annual Review of Sociology, 2(1), 335362.

Fairchild, K., \& Rudman, L. A. (2008). Everyday Stranger Harassment and Women's Objectification | SpringerLink. Social Justice Research, 21, 338-357.

Fazio, R. H., Effrein, E. A., \& Falender, V. J. (1981). Self-perceptions following social interaction. Journal of Personality and Social Psychology, 41(2), 232-242.

Gecas, V., \& Schwalbe, M. L. (1983). Beyond the Looking-Glass Self: Social Structure and Efficacy-Based Self-Esteem. Social Psychology Quarterly, 46(2), 77-88.

Gentile, B., Grabe, S., Dolan-Pascoe, B., Twenge, J. M., Wells, B. E., \& Maitino, A. (2009). Gender Differences in Domain-Specific Self-Esteem: A Meta-Analysis. Review of General Psychology, 13(1), 34-45.

Glick, P., Gangl, C., Gibb, S., Klumpner, S., \& Weinberg, E. (2007). Defensive Reactions to Masculinity Threat: More Negative Affect Toward Effeminate (but not Masculine) Gay Men. Sex Roles, 57(1-2), 55-59.

Greenaway, K. H., Cruwys, T., Haslam, S. A., \& Jetten, J. (2016). Social identities promote well-being because they satisfy global psychological needs. European Journal of Social Psychology, 46(3), 294-307.

Harder, D. H., \& Zalma, A. (1990). Two Promising Shame and Guilt Scales: A Construct Validity Comparison. Journal of Personality Assessment, 55(3-4), 729-745. 
Harrell, Z. A., Settles, I. H., Buchanan, N. T., Nnawulezi, N. A., \& Yap, S. C. (2011). The role of multiple social groups and identities in women's mental health. Women and Mental Disorders, 4, 1-31.

Haslam, S. A., Jetten, J., Postmes, T., \& Haslam, C. (2009). Social Identity, Health and WellBeing: An Emerging Agenda for Applied Psychology. Applied Psychology, 58(1), 123.

Hoffman, R. M. (2006). How Is Gender Self-Confidence Related to Subjective Well-Being? The Journal of Humanistic Counseling, Education and Development, 45(2), 186-197.

Hoffman, R. M., Borders, L. D., \& Hattie, J. A. (2000). Reconceptualizing femininity and masculinity: From gender roles to gender self-confidence. Journal of Social Behavior and Personality, 15(4), 475-503.

Hughes, M., Kiecolt, K. J., Keith, V. M., \& Demo, D. H. (2015). Racial Identity and WellBeing among African Americans. Social Psychology Quarterly, 78(1), 25-48.

Jackson, J. W. (2002). Intergroup Attitudes as a Function of Different Dimensions of Group Identification and Perceived Intergroup Conflict. Self and Identity, 1(1), 11-33.

Jetten, J., Branscombe, N. R., Schmitt, M. T., \& Spears, R. (2001). Rebels with a Cause: Group Identification as a Response to Perceived Discrimination from the Mainstream. Personality and Social Psychology Bulletin, 27(9), 1204-1213.

Khanna, N. (2004). The Role of Reflected Appraisals in Racial Identity: The Case of Multiracial Asians. Social Psychology Quarterly, 67(2), 115-131.

Kobrynowicz, D., \& Branscombe, N. R. (1997). Who Considers Themselves Victims of Discrimination?: Individual Difference Predictors of Perceived Gender Discrimination in Women and Men. Psychology of Women Quarterly, 21(3), 347363. 
Kroenke, K., Spitzer, R. L., \& Williams, J. B. W. (2001). The PHQ-9: Validity of a brief depression severity measure. Journal of General Internal Medicine, 16(9), 606-613.

Leach, C. W., van Zomeren, M., Zebel, S., Vliek, M. L. W., Pennekamp, S. F., Doosje, B., Ouwerkerk, J. W., \& Spears, R. (2008). Group-level self-definition and selfinvestment: A hierarchical (multicomponent) model of in-group identification. Journal of Personality and Social Psychology, 95(1), 144-165.

Levant, R. F., Hall, R. J., \& Rankin, T. J. (2013). Male Role Norms Inventory-Short Form (MRNI-SF): Development, confirmatory factor analytic investigation of structure, and measurement invariance across gender. Journal of Counseling Psychology, 60(2), $228-238$.

Linley, P. A., Maltby, J., Wood, A. M., Osborne, G., \& Hurling, R. (2009). Measuring happiness: The higher order factor structure of subjective and psychological wellbeing measures. Personality and Individual Differences, 47(8), 878-884.

Linville, P. W. (1985). Self-Complexity and Affective Extremity: Don't Put All of Your Eggs in One Cognitive Basket. Social Cognition, 3(1), 94-120.

Linville, P. W. (1987). Self-complexity as a cognitive buffer against stress-related illness and depression. Journal of Personality and Social Psychology, 52(4), 663-676.

Mahalik, J. R., Morray, E. B., Coonerty-Femiano, A., Ludlow, L. H., Slattery, S. M., \& Smiler, A. (2005). Development of the Conformity to Feminine Norms Inventory. Sex Roles: A Journal of Research, 52(7-8), 417-435.

Major, B., Quinton, W. J., \& McCoy, S. K. (2002). Antecedents and consequences of attributions to discrimination: Theoretical and empirical advances. In Advances in experimental social psychology, Vol. 34 (pp. 251-330). Academic Press. 
Major, B., Quinton, W. J., \& Schmader, T. (2003). Attributions to discrimination and selfesteem: Impact of group identification and situational ambiguity. Journal of Experimental Social Psychology, 39(3), 220-231.

McCoy, S. K., \& Major, B. (2003). Group Identification Moderates Emotional Responses to Perceived Prejudice. Personality and Social Psychology Bulletin, 29(8), 1005-1017. McKinley, N. M., \& Hyde, J. S. (1996). The Objectified Body Consciousness Scale: Development and Validation—Nita Mary McKinley, Janet Shibley Hyde, 1996. Psychology of Women Quarterly, 20, 181-215.

Muehlenkamp, J. J., \& Saris-Baglama, R. N. (2002). Self-Objectification and its Psychological Outcomes for College Women. Psychology of Women Quarterly, 26(4), $371-379$.

Nosek, B. A. (2005). Moderators of the Relationship Between Implicit and Explicit Evaluation. Journal of Experimental Psychology: General, 134(4), 565-584.

Oyserman, D. (2001). Self-concept and identity. In A. Tesser \& N. Schwarz (Eds.), The Blackwell Handbook of Social Psychology (pp. 499-517). Malden, MA: Blackwell.

Phinney, J. S., Cantu, C. L., \& Kurtz, D. A. (1997). Ethnic and American Identity as Predictors of Self-Esteem Among African American, Latino, and White Adolescents. Journal of Youth and Adolescence, 26(2), 165-185.

Ramos, M. R., Cassidy, C., Reicher, S., \& Haslam, S. A. (2012). A longitudinal investigation of the rejection-identification hypothesis. British Journal of Social Psychology, 51(4), $642-660$.

Rosenberg, M. (1965). Society and the adolescent self-image. Princeton, N.J.: Princeton university press.

Rosseel, Y. (2012). Lavaan: An R Package for Structural Equation Modeling. Journal of Statistical Software, 48(2), 1-36. 
Roszak, J. (2010). Culture as a factor influencing expression of one's own identity: Measuring gender identity. In A. Chybicka, S. Safdar, \& A. Kwiatkowska (Eds.), Culture and gender: An intimate relation (pp. 117-138).

Rowley, S. J., Sellers, R. M., Chavous, T. M., \& Smith, M. A. (1998). The relationship between racial identity and self-esteem in African American college and high school students. Journal of Personality and Social Psychology, 74(3), 715-724.

Rubin, M., \& Stuart, R. (2018). Kill or cure? Different types of social class identification amplify and buffer the relation between social class and mental health. The Journal of Social Psychology, 158(2), 236-251.

Rudman, L. A., \& Glick, P. (2012). The social psychology of gender: How power and intimacy shape gender relations. Guilford Press.

Sani, F., Herrera, M., Wakefield, J. R. H., Boroch, O., \& Gulyas, C. (2012). Comparing social contact and group identification as predictors of mental health. British Journal of Social Psychology, 51(4), 781-790.

Schmader, T. (2002). Gender Identification Moderates Stereotype Threat Effects on Women's Math Performance. Journal of Experimental Social Psychology, 38(2), 194-201.

Schmader, T., \& Block, K. (2015). Engendering Identity: Toward a Clearer Conceptualization of Gender as a Social Identity. Sex Roles, 73(11), 474-480.

Schmitt, M. T., Branscombe, N. R., Kobrynowicz, D., \& Owen, S. (2002). Perceiving Discrimination Against One's Gender Group has Different Implications for WellBeing in Women and Men. Personality and Social Psychology Bulletin, 28(2), 197210. 
Settles, I. H., Jellison, W. A., \& Pratt-Hyatt, J. S. (2009). Identification with multiple social groups: The moderating role of identity change over time among women-scientists. Journal of Research in Personality, 43(5), 856-867.

Shapiro, J. R., \& Neuberg, S. L. (2007). From Stereotype Threat to Stereotype Threats: Implications of a Multi-Threat Framework for Causes, Moderators, Mediators, Consequences, and Interventions. Personality and Social Psychology Review, 11(2), $107-130$.

Shih, M., Pittinsky, T. L., \& Ambady, N. (1999). Stereotype Susceptibility: Identity Salience and Shifts in Quantitative Performance. Psychological Science, 10(1), 80-83.

Simmons, J. P., Nelson, L. D., \& Simonsohn, U. (2011). False-Positive Psychology: Undisclosed Flexibility in Data Collection and Analysis Allows Presenting Anything as Significant. Psychological Science, 22(11), 1359-1366.

Sipe, S., Johnson, C. D., \& Fisher, D. K. (2009). University Students' Perceptions of Gender Discrimination in the Workplace: Reality Versus Fiction. Journal of Education for Business, 84(6), 339-349.

Smith, T. E., \& Leaper, C. (2006). Self-Perceived Gender Typicality and the Peer Context During Adolescence. Journal of Research on Adolescence, 16(1), 91-104.

Snell Jr, W. E., \& Godwin, L. (2013). Beliefs About Women Scale (BAWS). Measurement Instrument Database for the Social Science. https://www.midss.org/

Spence, J. T. (1999). Thirty years of gender research: A personal chronicle. In W. B. Swann, Jr., J. H. Langlois, \& L. A. Gilbert (Eds.), Sexism and stereotypes in modern society: The gender science of Janet Taylor Spence (pp. 255-289). American Psychological Association. 
Steele, C. M., Spencer, S. J., \& Aronson, J. (2002). Contending with group image: The psychology of stereotype and social identity threat. In Advances in Experimental Social Psychology (Vol. 34, pp. 379-440). Academic Press.

Swim, J. K., \& Miller, D. L. (1999). White Guilt: Its Antecedents and Consequences for Attitudes Toward Affirmative Action. Personality and Social Psychology Bulletin, 25(4), 500-514.

Tajfel, H. (1981). Human groups and social categories. Cambridge, England: Cambridge University Press.

Tajfel, H., \& Turner, J. C. (1979). An integrative theory of intergroup conflict. In W. G. Austin \& S. Worchel (Eds.), The social psychology of intergroup relations (pp. 3347).

Tate, C. C., Bettergarcia, J. N., \& Brent, L. M. (2015). Re-assessing the role of gender-related cognitions for self-esteem: The importance of gender typicality for cisgender adults. Sex Roles: A Journal of Research, 72(5-6), 221-236.

Tiggemann, M., \& Kuring, J. K. (2004). The role of body objectification in disordered eating and depressed mood. British Journal of Clinical Psychology, 43(3), 299-311.

Twenge, J. M., \& Campbell, W. K. (2002). Self-Esteem and Socioeconomic Status: A MetaAnalytic Review. Personality and Social Psychology Review, 6(1), 59-71.

Van Dick, R., Ketturat, C., Häusser, J. A., \& Mojzisch, A. (2017). Two sides of the same coin and two routes for improvement: Integrating resilience and the social identity approach to well-being and ill-health. Health Psychology Open, 4(2), 1-6.

Vandello, J. A., \& Bosson, J. K. (2013). Hard won and easily lost: A review and synthesis of theory and research on precarious manhood. Psychology of Men \& Masculinity, 14(2), 101-113. 
Vial, A. C., \& Napier, J. L. (2017). High power mindsets reduce gender identification and benevolent sexism among women (But not men). Journal of Experimental Social Psychology, 68, 162-170.

Wakefield, J. R. H., Sani, F., \& Herrera, M. (2018). Greater University Identification-But not Greater Contact—Leads to More Life Satisfaction: Evidence from a Spanish Longitudinal Study. Applied Psychology: Health and Well-Being, 10(2), 330-344.

Wang, K., \& Dovidio, J. F. (2017). Perceiving and Confronting Sexism: The Causal Role of Gender Identity Salience. Psychology of Women Quarterly, 41(1), 65-76.

Yap, S. C. Y., Settles, I. H., \& Pratt-Hyatt, J. S. (2011). Mediators of the relationship between racial identity and life satisfaction in a community sample of African American women and men. Cultural Diversity and Ethnic Minority Psychology, 17(1), 89-97. 


\section{Appendix}

Table A1

Studies 1-6 (Women): Complete Results of Multiple Regression Analyses

\begin{tabular}{|c|c|c|c|c|}
\hline \multicolumn{5}{|c|}{ Self-esteem } \\
\hline Study 1 & $\begin{array}{l}\text { Typicality } \\
\beta=.175, t(483)= \\
3.842, p<.001,95 \% \\
\text { CI }[0.085,0.265]\end{array}$ & $\begin{array}{l}\text { Acceptance } \\
\beta=.540, t(483)= \\
9.856, p<.001,95 \% \\
\text { CI }[0.432,0.647]\end{array}$ & $\begin{array}{l}\text { Definition } \\
\beta=-.291, t(483)= \\
-5.170, p<.001, \\
95 \% \text { CI }[-0.402,- \\
0.180]\end{array}$ & $\begin{array}{l}R^{2}=.225, F(3,483)= \\
46.84, p<.001\end{array}$ \\
\hline Study 2 & $\begin{array}{l}\beta=.112, t(636)= \\
2.882, p=.004,95 \% \\
\text { CI }[0.036,0.188]\end{array}$ & $\begin{array}{l}\beta=.509, t(636)= \\
11.575, p<.001,95 \% \\
\text { CI }[0.423,0.595]\end{array}$ & $\begin{array}{l}\beta=-.254, t(636)= \\
-5.683, p<.001, \\
95 \% \text { CI [-0.342,- } \\
0.166]\end{array}$ & $\begin{array}{l}R^{2}=.203, F(3,636)= \\
54.08, p<.001\end{array}$ \\
\hline Study 4 & $\begin{array}{l}\beta=.231, t(196)= \\
3.585, p<.001,95 \% \\
\text { CI }[0.104,0.385]\end{array}$ & $\begin{array}{l}\beta=.633, t(196)= \\
7.401, p<.001,95 \% \\
\text { CI }[0.464,0.801]\end{array}$ & $\begin{array}{l}\beta=-.264, t(196)= \\
-3.205, p=.002, \\
95 \% \text { CI [-0.427, - } \\
0.102]\end{array}$ & $\begin{array}{l}R^{2}=.369, F(3,196) \\
=38.18, p<.001\end{array}$ \\
\hline Study 6 & $\begin{array}{l}\text { Ingroup ties } \\
\beta=.139, t(1111)= \\
4.703, p<.001,95 \% \\
\text { CI }[0.081,0.197]\end{array}$ & $\begin{array}{l}\text { Ingroup affect } \\
\beta=.414, t(1111)= \\
14.371, p<.001,95 \% \\
\text { CI }[0.358,0.471]\end{array}$ & $\begin{array}{l}\text { Centrality } \\
\beta=-.090, t(1111)= \\
-3.277, p=.001, \\
95 \% \text { CI [-0.143, - } \\
0.036]\end{array}$ & $\begin{array}{l}R^{2}=.227, F(3,1111) \\
=109.0, p<.001\end{array}$ \\
\hline \multicolumn{5}{|c|}{ Shame } \\
\hline Study 3 & $\begin{array}{l}\text { Typicality } \\
\beta=-.021, t(632)= \\
-0.481, p=.631, \\
95 \% \text { CI [-0.107, } \\
0.065]\end{array}$ & $\begin{array}{l}\text { Acceptance } \\
\beta=-.392, t(632)= \\
-8.102, p<.001,95 \% \\
\text { CI }[-0.487,-0.297]\end{array}$ & $\begin{array}{l}\text { Definition } \\
\beta=.224, t(632)= \\
4.566, p<.001,95 \% \\
\text { CI }[0.128,0.320]\end{array}$ & $\begin{array}{l}R^{2}=.102, F(3,632)= \\
23.85, p<.001\end{array}$ \\
\hline Study 4 & $\begin{array}{l}\beta=-.182, t(196)= \\
-2.538, p=.012, \\
95 \% \text { CI }[-0.324,- \\
0.041]\end{array}$ & $\begin{array}{l}\beta=-.529, t(196)= \\
-5.547, p<.001,95 \% \\
\text { CI }[-0.717,-0.341]\end{array}$ & $\begin{array}{l}\beta=.317, t(196)= \\
3.451, p<.001,95 \% \\
\text { CI }[0.136,0.499]\end{array}$ & $\begin{array}{l}R^{2}=.215, F(3,196) \\
=17.86, p<.001\end{array}$ \\
\hline Study 6 & $\begin{array}{l}\text { Ingroup ties } \\
\beta=-.114, t(1111)=- \\
3.648, p<.001,95 \% \\
\text { CI }[-0.176,-0.358]\end{array}$ & $\begin{array}{l}\text { Ingroup affect } \\
\beta=-.298, t(1111)=- \\
9.765, p<.001,95 \% \\
\text { CI }[-0.358,-0.238]\end{array}$ & $\begin{array}{l}\text { Centrality } \\
\beta=.161, t(1111)= \\
5.563, p<.001,95 \% \\
\text { CI }[0.105,0.218]\end{array}$ & $\begin{array}{l}R^{2}=.132, F(3,1111) \\
=56.07, p<.001\end{array}$ \\
\hline \multicolumn{5}{|c|}{ Guilt } \\
\hline Study 3 & $\begin{array}{l}\text { Typicality } \\
\beta=-.034, t(632)= \\
-0.750, p=.454, \\
95 \% \text { CI }[-0.121, \\
0.054]\end{array}$ & $\begin{array}{l}\text { Acceptance } \\
\beta=-.275, t(632)= \\
-5.525, p<.001,95 \% \\
\text { CI }[-0.372,-0.177]\end{array}$ & $\begin{array}{l}\text { Definition } \\
\beta=.173, t(632)= \\
3.437, p<.001,95 \% \\
\text { CI }[0.074,0.272]\end{array}$ & $\begin{array}{l}R^{2}=.052, F(3,632)= \\
11.58, p<.001\end{array}$ \\
\hline
\end{tabular}




\begin{tabular}{lllll} 
Study 4 & $\beta=-.182, t(196)=$ & $\beta=-.364, t(196)=$ & $\beta=.240, t(196)=$ & $R^{2}=.124, F(3,477)$ \\
& $-2.399, p=.017$, & $-3.619, p<.001,95 \%$ & $2.475, p=.014,95 \%$ & $=9.249, p<.001$ \\
& $95 \%$ CI $[-0.332,-$ & CI $[-0.563,-0.166]$ & CI $[0.0489,0.432]$ & \\
& $0.032]$ & & & \\
\hline \multirow{3}{*}{ Study 6 } & Ingroup ties & Ingroup affect & Centrality & \\
& $\beta=-.063, t(1111)=-$ & $\beta=-.278, t(1111)=-$ & $\beta=.201, t(1111)=$ & $R^{2}=.112, F(3,1111)$ \\
& $1.979, p<.001,95 \%$ & $8.995, p<.001,95 \%$ & $6.856, p<.001,95 \%$ & $=46.89, p<.001$ \\
& CI $[-0.125,-0.0005]$ & CI $[-0.338,-0.217]$ & CI $[0.144,0.259]$ &
\end{tabular}

\section{Depressive symptoms}

\begin{tabular}{lllll}
\hline \multirow{3}{*}{ Study 4} & Typicality & Acceptance & Definition & \\
& $\beta=-.277, t(196)=$ & $\beta=-.438, t(196)=$ & $\beta=.223, t(196)=$ & $R^{2}=.240, F(3,196)$ \\
& $-3.923, p<.001$, & $-4.667, p<.001,95 \%$ & $2.468, p=.014,95 \% \quad=20.68, p<.001$ \\
& $95 \%$ CI $[-0.416,-$ & CI $[-0.623,-0.253]$ & CI $[0.045,0.402]$ & \\
& $0.138]$ & & & \\
\hline
\end{tabular}

\section{Life satisfaction}

\begin{tabular}{lllll}
\hline \multirow{3}{*}{ Study 4} & Typicality & Acceptance & Definition & \\
& $\beta=.293, t(196)=$ & $\beta=.535, t(196)=$ & $\beta=-.230, t(196)=$ & $R^{2}=.340, F(3,196)$ \\
& $4.455, p<.001,95 \%$ & $6.123, p<.001,95 \%$ & $-2.728, p<.001$, & $=33.62, p<.001$ \\
& CI $[0.163,0.423]$ & CI $[0.363,0.708]$ & $95 \%$ CI $[-0.396,-$ & \\
& & & $0.064]$ & \\
\hline
\end{tabular}

Self-objectification

\begin{tabular}{lllll}
\hline & Typicality & Acceptance & Definition & \\
Study 5 & $\beta=.065, t(564)=$ & $\beta=-.429, t(564)=$ & $\beta=.376, t(564)=$ & $R^{2}=.146, F(3,564)=$ \\
& $1.482, p=.139,95 \%$ & $-8.866, p<.001,95 \%$ & $7.819, p<.001,95 \%$ & $32.15, p<.001$ \\
& CI $[-0.021,0.150]$ & CI $[-0.524,-0.334]$ & CI $[0.281,0.471]$ & \\
& & & & \\
Study 6 & Ingroup ties & Ingroup affect & Centrality & \\
& $\beta=.013, t(1111)=$ & $\beta=-.242, t(1111)=$ & $\beta=.256, t(1111)=$ & $R^{2}=.105, F(3,1111)$ \\
& $0.404, p=.404,95 \%$ & $-7.798, p<.001,95 \%$ & $8.687, p<.001,95 \%$ & $=43.50, p<.001$ \\
& CI $[-0.050,0.075]$ & CI $[-0.303,-0.181]$ & CI $[0.198,0.314]$ &
\end{tabular}


Table A2

Studies 7-10 (Men): Complete Results of Multiple Regression Analyses

\begin{tabular}{|c|c|c|c|c|}
\hline \multicolumn{5}{|c|}{ Self-esteem } \\
\hline Study 7 & $\begin{array}{l}\text { Typicality } \\
\beta=.148, t(534)= \\
3.335, p<.001,95 \% \\
\text { CI }[0.061,0.235]\end{array}$ & $\begin{array}{l}\text { Acceptance } \\
\beta=.467, t(534)= \\
10.148, p<.001,95 \% \\
\text { CI }[0.376,0.557]\end{array}$ & $\begin{array}{l}\text { Definition } \\
\beta=-.120, t(534)= \\
-2.668, p=.008, \\
95 \% \text { CI [-0.209, - } \\
0.032]\end{array}$ & $\begin{array}{l}R^{2}=.247, F(3,534) \\
=58.380, p<.001\end{array}$ \\
\hline Study 9 & $\begin{array}{l}\text { Ingroup ties } \\
\beta=.160, t(582)= \\
3.777, p<.001,95 \% \\
\text { CI }[0.077,0.243]\end{array}$ & $\begin{array}{l}\text { Ingroup affect } \\
\beta=.328, t(582)= \\
7.639, p<.001,95 \% \\
\text { CI }[0.243,0.412]\end{array}$ & $\begin{array}{l}\text { Centrality } \\
\beta=-.101, t(582)= \\
-2.642, p=.008, \\
95 \% \text { CI [-0.176, - } \\
0.026]\end{array}$ & $\begin{array}{l}R^{2}=.176, F(3,582) \\
=41.470, p<.001\end{array}$ \\
\hline \multicolumn{5}{|c|}{ Shame } \\
\hline Study 8 & $\begin{array}{l}\text { Typicality } \\
\beta=-.093, t(572)= \\
-1.962, p=.050, \\
95 \% \text { CI [-0.186, } \\
0.001]\end{array}$ & $\begin{array}{l}\text { Acceptance } \\
\beta=-.251, t(572)= \\
-4.954, p<.001,95 \% \\
\text { CI }[-0.351,-0.152]\end{array}$ & $\begin{array}{l}\text { Definition } \\
\beta=.110, t(572)= \\
2.212, p=.027,95 \% \\
\text { CI }[0.012,0.208]\end{array}$ & $\begin{array}{l}R^{2}=.969, F(3,572) \\
=13.610, p<.001\end{array}$ \\
\hline Study 10 & $\begin{array}{l}\text { Ingroup ties } \\
\beta=-.142, t(605)= \\
-3.244, p=.001, \\
95 \% \text { CI }[-0.228,- \\
0.056]\end{array}$ & $\begin{array}{l}\text { Ingroup affect } \\
\beta=-.166, t(605)= \\
-3.716, p<.001,95 \% \\
\text { CI }[-0.254,-0.078]\end{array}$ & $\begin{array}{l}\text { Centrality } \\
\beta=.158, t(605)= \\
3.962, p<.001,95 \% \\
\text { CI }[0.080,0.239]\end{array}$ & $\begin{array}{l}R^{2}=.082, F(3,605) \\
=17.930, p<.001\end{array}$ \\
\hline \multicolumn{5}{|c|}{ Guilt } \\
\hline Study 8 & $\begin{array}{l}\text { Typicality } \\
\beta=-.157, t(572)= \\
-3.313, p<.001, \\
95 \% \text { CI [-0.249, - } \\
0.064]\end{array}$ & $\begin{array}{l}\text { Acceptance } \\
\beta=-.199, t(572)= \\
-3.921, p<.001,95 \% \\
\text { CI }[-0.298,-0.099]\end{array}$ & $\begin{array}{l}\text { Definition } \\
\beta=.095, t(572)= \\
1.901, p=.058,95 \% \\
\text { CI }[-0.003,0.193]\end{array}$ & $\begin{array}{l}R^{2}=.069, F(3,572) \\
=14.070, p<.001\end{array}$ \\
\hline Study 10 & $\begin{array}{l}\text { Ingroup ties } \\
\beta=-.077, t(605)= \\
-1.767, p=.078, \\
95 \% \text { CI [-0.163, } \\
0.009]\end{array}$ & $\begin{array}{l}\text { Ingroup affect } \\
\beta=-.223, t(605)= \\
-5.010, p<.001,95 \% \\
\text { CI }[-0.311,-0.136]\end{array}$ & $\begin{array}{l}\text { Centrality } \\
\beta=.194, t(605)= \\
4.894, p<.001,95 \% \\
\text { CI }[0.116,0.272]\end{array}$ & $\begin{array}{l}R^{2}=.090, F(3,605) \\
=19.960, p<.001\end{array}$ \\
\hline \multicolumn{5}{|c|}{ Life satisfaction } \\
\hline Study 8 & $\begin{array}{l}\text { Typicality } \\
\beta=.232, t(572)= \\
5.118, p<.001,95 \% \\
\text { CI }[0.143,0.321]\end{array}$ & $\begin{array}{l}\text { Acceptance } \\
\beta=.274, t(572)= \\
5.630, p<.001,95 \% \\
\text { CI }[0.178,0.369]\end{array}$ & $\begin{array}{l}\text { Definition } \\
\beta=-.110, t(572)= \\
-2.296, p=.022, \\
95 \% \text { CI [-0.203, - } \\
0.016]\end{array}$ & $\begin{array}{l}R^{2}=.145, F(3,572) \\
=32.380, p<.001\end{array}$ \\
\hline & Ingroup ties & Ingroup affect & Centrality & \\
\hline
\end{tabular}



Study $10 \quad \beta=.157, t(605)=\quad \beta=.192, t(605)=$ $3.587, p<.001,95 \% \quad 4.316, p<.001,95 \%$ CI $[0.071,0.243]$ CI $[0.105,0.28]$
$\beta=-.037, t(605)=\quad R^{2}=.087, F(3,605)$ $-0.939, p=.348, \quad=19.210, p<.001$ $95 \%$ CI $[-0.115$, $0.041]$

Self-objectification

\begin{tabular}{lllll}
\hline \multirow{4}{*}{ Study 7} & Typicality & Acceptance & Definition & \\
& $\beta=-.129, t(534)=-$ & $\beta=-.280, t(534)=$ & $\beta=.277, t(534)=$ & $R^{2}=.096, F(3,534)=$ \\
& $2.659, p=.008,95 \%$ & $-5.553, p<.001,95 \%$ & $5.605, p<.001,95 \%$ & $18.930, p<.001$ \\
& CI $[-0.224,-0.034]$ & CI $[-0.379,-0.181]$ & CI $[0.180,0.374]$ & \\
\hline \multirow{4}{*}{ Study 9} & Ingroup ties & Ingroup affect & Centrality & \\
& $\beta=-.169, t(582)=$ & $\beta=-.082, t(582)=$ & $\beta=.243, t(582)=$ & $R^{2}=.092, F(3,582)$ \\
& $-3.799, p<.001$, & $-1.827, p=.068,95 \%$ & $6.057, p<.001,95 \%$ & $=19.760, p<.001$ \\
& $95 \%$ CI $[-0.256,-$ & CI $[-0.171,0.006]$ & CI $[0.164,0.322]$ & \\
& $0.081]$ & & & \\
\hline
\end{tabular}

Table A3

Studies 11-14: Zero-Order Correlations Between Gender Identity and Well-Being

\begin{tabular}{|c|c|c|c|c|}
\hline & & Gender & $\begin{array}{l}\text { Self- } \\
\text { esteem }\end{array}$ & $\begin{array}{l}\text { Depressive } \\
\text { symptoms }\end{array}$ \\
\hline \multirow{2}{*}{ Typicality } & Study 11 & $f$ & $.139 * *$ & $-.104 *$ \\
\hline & Study 12 & $\mathrm{~m}$ & $.259 * * *$ & $-.168 * * *$ \\
\hline \multirow{2}{*}{ Definition } & Study 11 & $f$ & $.107^{*}$ & -.015 \\
\hline & Study 12 & $\mathrm{~m}$ & $.148^{* * * *}$ & -.039 \\
\hline \multirow{2}{*}{ Acceptance } & Study 11 & $f$ & $.354 * * *$ & $-.135 * *$ \\
\hline & Study 12 & $\mathrm{~m}$ & $.427 * * *$ & $-.163 * * *$ \\
\hline \multirow{2}{*}{ Ingroup affect } & Study 13 & $f$ & $.398 * * *$ & $-.189 * * *$ \\
\hline & Study 14 & $\mathrm{~m}$ & $.429 * * *$ & $-.163 * * *$ \\
\hline \multirow{2}{*}{ Centrality } & Study 13 & $f$ & -.033 & .019 \\
\hline & Study 14 & $\mathrm{~m}$ & -.051 & $.128 * *$ \\
\hline \multirow{2}{*}{ Ingroup ties } & Study 13 & $f$ & $.239 * * *$ & $-.144 * * *$ \\
\hline & Study 14 & $\mathrm{~m}$ & $.382 * * *$ & $-.266 * * *$ \\
\hline \multicolumn{5}{|c|}{ Note. $* * * p<.001 ; * * p<.01 ; * p<.05$} \\
\hline
\end{tabular}


Table A4

Studies 11-14: Complete Results of Multiple Regression Analyses

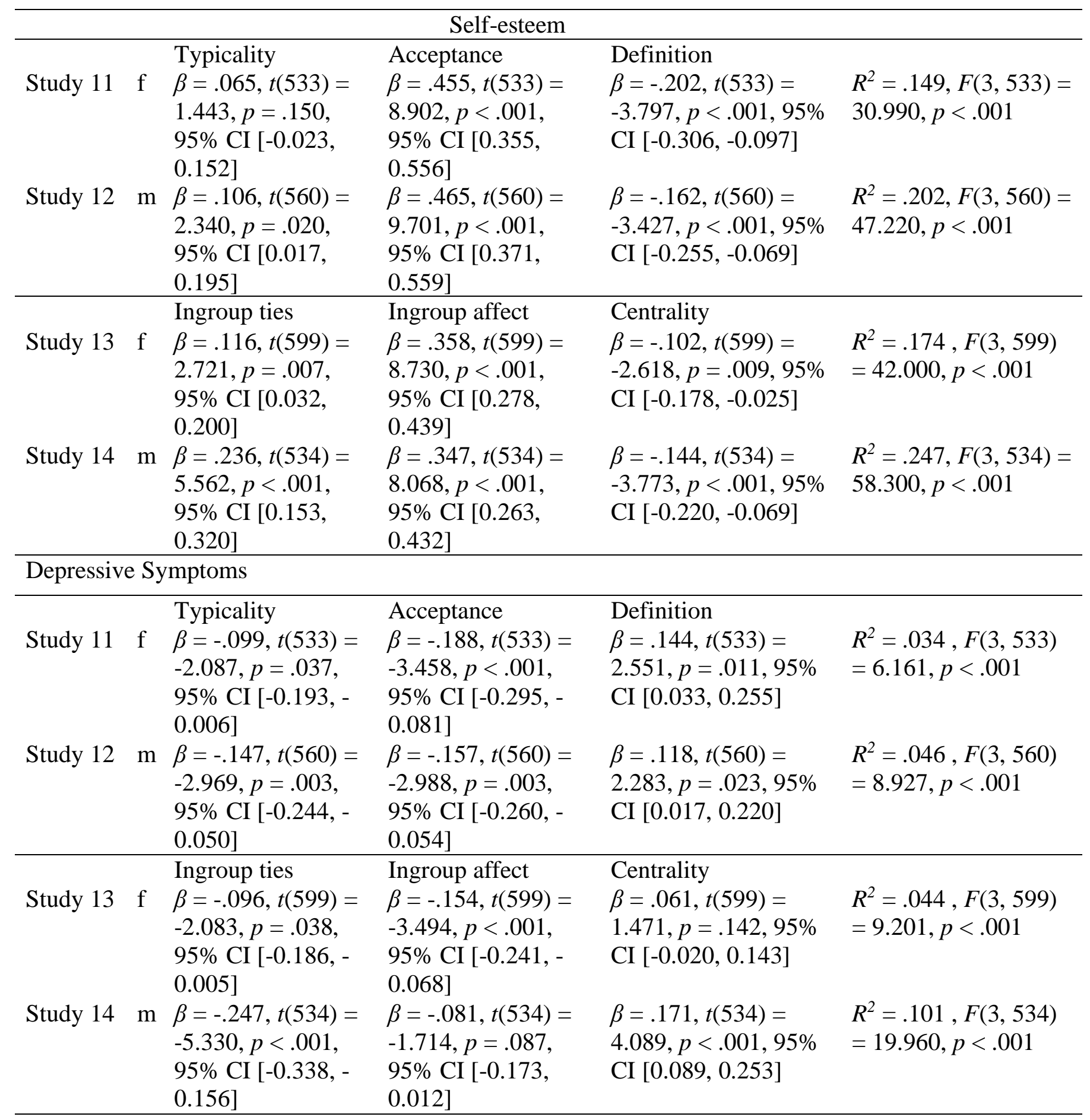

